\title{
Comments
}

\section{CRIMINAL WAIVER: THE REQUIREMENTS OF PERSONAL PARTICIPATION, COMPETENCE AND LEGITIMATE STATE INTEREST}

The past decade has witnessed the expansion of a number of the federal rights which constitute the arsenal of the criminal defendant. ${ }^{1}$ Noncomplance with any of these guarantees normally creates a ground for reversal upon appellate review or collateral attack. It is possible, however, that a state or federal court would refuse to review the conviction on its merits, invoking the concept of waiver and-in federal review of state criminal proceedings-the jurisdictional doctrines of adequate state grounds or exhaustion of state remedies. Whichever basis is used, the effect is normally the same: The defendant is foreclosed from pressing the inerits of his constitutional claims, unless he can cure the past procedural defect or persuade the reviewing court to overlook it.

The jurisdictional barriers which once precluded review of the "abortive state proceeding"' and so thoroughly divided the Supreme Court ${ }^{3}$ have been fully analyzed by Professors Hart, ${ }^{4}$ Reitz, ${ }^{5}$ and Bator. ${ }^{6}$ Receut decisions have, for the most part, resolved those questions. It is now fairly clear that, with the exception of a deliberate bypass, ${ }^{7}$ the jurisdiction of federal courts is not precluded by procedural defaults in the state criminal trial either on habeas corpus review ${ }^{8}$ or on direct appeal to the Supreme Court. ${ }^{9}$

1 E.g., Estes v. Texas, 381 U.S. 532 (1965) (trial free from unreasonable publicity); Griffin v. California, 380 U.S. 609 (1965) (prohibition of comment to the jury on defendant's failure to testify); Escobedo v. Mlinois, 378 U.S. 478 (1964) (exclusion of confession obtained after violation of right to counsel); Haynes v. Washington, 37.3 U.S. 503 (1963) (exclusion of coerced confession); Gideon v. Wainwriglt, 372 U.S. 335 (1963) (counsel); Wong Sun v. United States, 371 U.S. 471 (1963) (exclusion of verbal evidence after un. lawful arrest or search); Mapp v. Ohio, 367 U.S. 643 (1961) (exclusion of the fruits of an illegal search).

2 This term was coined by Reitr, Federal Habeas Corprus: Impact of an Abortive State Proceeding, 74 HaRv. L. REv. 1315 (1961).

3 See, e.g., the various opinions expressed in Brown v. Allen, 344 U.S. 443 (1953).

4 Hart, Forward: The Time Chart of the Justices, 73 HaRv. L. REv. 84 (1959).

5 Reitz, supra note 2.

'Bator, Finality in Criminal Law and Federal Habeas Corpus for State Prisoners, 76 HARv. L. REv. 441 (1963). Two other discussions of the labeas corpus jurisdiction of federal courts ean be found in Note, 39 N.Y.U.L. R.Ev. 78 (1964); 62 ColuM. L. Rev. 1077 (1962).

7 Henry v. Mississippi, 379 U.S. 443, 450-51 (1965); Fay v. Noia, 372 U.S. 391,439 (1963).

8 Fay v. Noia, supra note 7 , at 438.

${ }^{9}$ Henry v. Mississippi, 379 U.S. 443,447 (1965). See Sandalow, Henry v. Mississippi and the Adequate State Ground: Proposals for a Revised Doctrine, 1965 Sup. Cr. Rev. 187. 
As a result of the removal of these jurisdictional barriers, strict compliance with procedural rules has become less crucial, and the concept of waiver has become the principal device by which courts have refused to hear the merits of constitutional claims. However, it has become increasingly difficult to determine when a defendant has decided to effect a waiver and thus forego his claim to a particular right. In Johnson $v$. $Z e r b s t^{10}$ the Court defined a waiver as "an intentional relinquishment or abandonment of a known right or privilege" ${ }^{\prime 11}$ and held that nothing less would bind the accused. However, many state and federal courts, including the Supreme Court, failed to follow the Johnson test strictly: They continued to apply the doctrine of waiver upon finding any procedural omission, despite defendant's lack of either knowledge or intent. ${ }^{12}$ Factors were often cited to override or vitiate the necessity of the requirements which the Supreme Court had laid down in Johnson: The presumption against an unintelligent waiver, ${ }^{13}$ defendant's legal background, ${ }^{14}$ the absence of exceptional circumstances ${ }^{15}$ and the fear of abuse of the new standard ${ }^{16}$ were given as reasons for holding the accused to an unintentional or incompetent waiver. Therefore, a quarter of a century later the Court in Fay v. Noia ${ }^{17}$ felt itself constrained to re-emphasize certain

The reason which the Court gives as a general justification for this liberalization is directly related to its rejection in Fay $v$. Noia of the doctrine of adequate state grounds in federal habeas hearings. Since the habeas courts can overlook all but deliberate noncomphance with state procedure, principles of judicial efficiency would seem to demand that the Court hear the merits of the federal issue on direct review if at all possible, thereby perhaps saving an entire round of federal habeas corpus proceedings. Compare Fay v. Noia, 372 U.S. 391,438 (1963) and Townsend v. Sain, 372 U.S. 293, 317 (1963), with Henry v. Mississippi, supra at 452-53. If this approach strains traditional notions of comity, the Court feels that this defect is compensated by the fact that, on direct appeal, the case can be remanded to the state court for factual findings as to the deliberate nature of the noncompliance. This complements the judicial efficiency argument, since federal habeas courts would also be precluded from hearing the merits if intentional noncompliance were found. Fay v. Noia, supra at 438 .

10304 U.S. 458 (1938).

11 Id. at 464 .

12 E.g., Daniels v. Allen, reported with Brown v. Allen, 344 U.S. 443 (1953); Rivera v. United States, 318 F.2d 606 (9th Cir. 1963); O'Malley v. United States, 285 F.2d 733 (6th Cir. 1961); Mitchell v. United States, 259 F.2d 787 (D.C. Cir.), cert. denied, 358 U.S. 850 (1958); Tompsett v. Ohio, 146 F.2d 95 (6th Cir. 1944), cert. denied, 324 U.S. 869 (1945); People v. Rodriguez, 143 Cal. App. 2d 506, 299 P.2d 1057 (1956).

13 See, e.g., Moore v. Michigan, 355 U.S. 155, 161-62 (1957).

14 See, e.g., Crooker v. California, 357 U.S. 433 (1958); Kinney v. United States, 177 F.2d 895 (10th Cir. 1949), cert. denied, 339 U.S. 922 (1950).

$15 \mathrm{See}$, e.g., Mitchell v. United States, 259 F.2d 787 (D.C. Cir.), cert. denied, 358 U.S. 850 (1958); United States ex rel. Kozicky v. Fay, 248 F.2d 520 (2d Cir. 1957), cert. denied, 356 U.S. 960 (1958). (1952).

10 E.g., People v. Mitchell, 411 III. 407, 104 N.E.2d 285, cert. denied, 343 U.S. 969

17372 U.S. 391 (1963). 
aspects of the concept. While maintaining Johnson's "classic definition" as the controlling standard, the Court went on to clarify the prerequisites of knowledge and intent in the context of federal habeas corpus litigation:

If a habeas applicant, after consultation with competent counsel or otherwise, understandingly and knowingly forewent the privilege of seeking to vindicate his federal claims in the state courts, whether for strategic, tactical, or any other reasons that can fairly be described as the deliberate bypassing of state procedures, then it is open to the federal court on habeas to deny him all relief if the state courts refused to entertain his federal claims on the merits .... At all events we wish it clearly understood that the standard here put forth depends on the considered choice of the petitioner..$^{18}$

The effects of this restatement have varied considerably since its publication. Some courts, both state and federal, have taken the opportunity provided by Fay $v$. Noia to increase the defendant's procedural protection against inadvertent or incompetent waiver by requiring a waiver to be made personally and intelligently by the defendant. ${ }^{10}$ Other courts have continued to insist on strict complance with procedural requirements, thereby avoiding a hearing on the merits of the constitutional issue. ${ }^{20}$

The case of Henry $v$. Mississippi ${ }^{21}$ is a typical example of the subject matter of a waiver and the procedural framework in which the question arises. Aaron Henry, a Mississippi civil rights leader, was convicted of disturbing the peace after le allegedly gave a ride to a young hitchhiker. The latter accused Henry of advancing indecent proposals and making offensive contacts; and at trial the testimony of the complainant describing the interior of defendant's automobile was corroborated ${ }^{22}$ by the statements of the arresting officer. Despite the Mississippi contemporaneous objection rule, no objection was offered to the introduction of this testimony ${ }^{23}$ until the close of the state's case, at which time Henry's

18 Id. at 439. (Emphasis added.)

19 See, e.g., Whitus v. Balkcom, 333 F.2d 496 (5th Cir.), cert. denied, 379 U.S. 931 (1964); Brubaker v. Dickson, 310 F.2d 30 (9th Cir. 1962), cert. denied, 372 U.S. 978 (1963); Poe v. United States, 233 F. Supp. 173 (D.D.C. 1964); State v. Mendes, 210 A.2d 50 (R.I. 1965).

20 See, e.g., Nelson v. State of California, 346 F.2d 73 (9th Cir. 1965); People v. Campbell, 233 Cal. App. 2d 38, 43 Cal. Rptr. 237 (1965).

21379 U.S. 443 (1965).

22 In Mississippi, a defendant cannot be convicted on complainant's testimony alone. There must be corroborating testimony. Therefore, the officer's statements were crucial to the conviction. Id. at 444 . The testimony here corroborated complainant's description of the car rather than the alleged acts. This tended to prove complainant's presence in Henry's car.

23 The Supreme Court cited two possible reasons for a dehberate bypass by Henry's counsel: The defense could allow the officer's testimony to be introduced and then, if the directed verdict failed, discredit him by proving his testimony incorrect. The defense attorneys also could have hoped to induce error and thereby lay the foundation for a later reversal. $I d$. at 451 . 
counsel entered a motion for a directed verdict. ${ }^{24}$ The motion, which was denied, included the argument that the officer's evidence had been the product of an illegal search. The Mississippi Supreme Court, on appeal, held the corroborative testimony to be inadmissible. ${ }^{25}$ The court further ruled that since Henry's nonresident counsel was unfamihar with local procedure, the defendant would not be held to strict comphance with the contemporaneous objection rule. However, upon the filing of a Suggestion of Error which established that defense counsel had been assisted by a local attorney, the state supreme court issued a new opinion. ${ }^{26}$ It reiterated the inadmissibility of the officer's testimony but lield that counsel's failure to make a timely objection thereto effectively waived Henry's right to object to the admission of such statements. ${ }^{27}$ The United States Supreme Court granted certiorari ${ }^{28}$ and, in January, 1965, vacated the conviction, holding that the purposes of the contemporaneous objection rule might have been satisfied by the motion for directed verdict. ${ }^{29}$ There was, though, evidence to the effect that one of defendant's counsel stood up as if to object to the officer's testimony but was "pulled down" by co-counsel. Therefore, the Court remanded for a factual determination of whether or not there had been a "deliberate bypass" in order to evaluate the binding effect of the procedural default. ${ }^{30}$ Since the essential testimony in Henry was deemed to be inadmissible, the entire conviction rested on defendant's noncomphance with state procedure and his resulting inability to get a hearing on the merits of his objection.

The conflict in Henry is typical of the friction between procedural requirements for the presentation of substantive issues ${ }^{31}$ and the federal obligation to ensure defendants their constitutional protections. This tension has become even more pronounced in recent years: The effective expansion of the Bill of Rights guarantees has been considerably himited by a corresponding rise in the chances for both intentional and uninten-

24 Henry's wife had given the officer permission to search the car. Defendant's ground for objection to the policeman's testimony was that the wife could not waive her lussband's constitutional riglits in this manner. $I d$. at 445.

25 Henry v. State, 154 So. $2 \mathrm{~d} 289$ (Miss. 1963) (advance sheets), withdrawn in favor of 154 So. 2d 289 (Miss, 1963) (bound volume), vacated, Henry v. Mississippi, 379 U.S. 443 (1965).

26154 So. 2d 289 (Miss. 1963) (bound volume), vacated, 379 U.S. 443 (1965).

27 Id. at 295 .

28376 U.S. 904 (1964).

29379 U.S. at 448.

30 Id. at 451-53.

31 The state lias a legitimate interest in insisting on compliance with the contemporaneous objection rule, for instance, since it both alerts the court to a possible error so that tainted evidence will be kept from the jury and prevents the accused from deliberately using the mistake as a means to a new trial if the jury renders an adverse verdict. See Henry v. Mississippi, 379 U.S. 443, 448 (1965). 
tional waivers at all stages of the trial procedure. Therefore, the principal problem facing the courts in this area is the identification and application of the procedural waiver at the trial level.

This Comment will analyze the factors affecting the binding nature of a purported waiver and their applicability to the acts of counsel, defendant, and court. While not every waiver need be personally effected by the defendant, there inust frequently be some participation by the accused when the right waived is a fundamental one. Part I will evaluate the need for personal participation and will examine the desirability of this requirement, especially at pre-trial, in relation to the fairness and efficiency of the judicial process. The "deliberate bypass" standard, as applied to both defendant and attorney, will be supported as a means of fully effectuating the Johnson requirement of a knowing and intelligent waiver. In examining the effects of counsel's incompetent waivers, part II will demonstrate the inapplicability of agency principles to the criminal trial and the relative misuse of the "mockery of justice" guideline which purports to correct the trial which turns out to be a farce. Rather, a standard is proposed which would judge the defense presented in relation to those not offered in order to determine if the choice was an informed and deliberate one. Part III will examine the courts' emphasis on exceptional circumstances and will evaluate the resulting flexibility and uncertainty which the standard presents. The courts' consideration of other factors, such as defendant's background and recordation of the waiver, will be analyzed in parts IV and $V$ as a means of preventing fraudulent claims of unintentional waiver. Finally, the state's interest in the procedure which was bypassed has become an important factor in protecting the defendant from an arbitrary application of procedural requirements. The desirability of this inquiry will be emphasized in part VI, and the legitimate state interest will be analyzed as a. means of protecting this federal government interest in federal rights and as a basis for vitiating the purported waiver in order to hear the federal issue on its merits.

\section{I}

THE NECESSITY FOR PERSONAL WATVER

A factor which permeates the courts' resolution of almost every waiver problem is the relationship between defendant and his counsel. The Fay v. Noia "dehberate bypass" test posits a method for the determination of some of the factors necessary for a waiver to be found; yet it deals far too generally with the crucial question of who may make the deliberate bypass. While Fay advances the proposition that defendant must participate in the decision in order to be bound by the waiver, ${ }^{32}$ no

32372 U.S. at 439. 
court could possibly take this as a universally applicable requirement. There are too many decisions, such as the method of cross examination, which must be left to counsel. ${ }^{33}$ Therefore, the $F a y$ holding on this point must be limited to the specific decision of whether or not to waive basic procedural rights, such as the appellate process; and the question of the general necessity of a personal waiver has been left open.

\section{A. The Nature of the Right Waived}

An evaluation of the importance of the right waived may be a material consideration in the determination of the need for a personal waiver. Certain basic protections, such as the entry of a plea or the right to a petit jury, have been deemed to be essential; ${ }^{34}$ and most courts have refused to accept a nonpersonal waiver of these rights without first ascertaining from the defendant himself that this action was done with both his permission and his awareness of the consequences. ${ }^{35}$ Thus, most courts, either expressly or impliedly, have made a distinction between such "fundamental rights" and other "trial decisions." held that while the right to testify is personal to the accused, the decision to cross examine an essential witness may be left to his attorney. ${ }^{37}$ Perhaps the most striking example of using this distinction to vitiate a prior deliberate waiver is to be found in United States ex rel. Goldsby $v$. Harpole..$^{38}$ The court was willing to nullify the nonpersonal waiver of the objection to the petit jury, because the composition of that jury was deemed to be a fundamental aspect of a fair trial. ${ }^{39}$ However, under

33 E.g., Rhay v. Browder, 342 F.2d 345 (9th Cir. 1965); Kennedy v. United States, 259 F,2d 883 (5th Cir. 1958), cert. denied, 359 U.S. 994 (1959); Poe v. United States, 233 F. Supp. 173 (D.D.C. 1964). But see Henderson v. Heinze, 349 F.2d 67, 68-69 (9th Cir. 1965); State v. Mendes, 210 A.2d 50 (R.I. 1965).

34 E.g., People v. Blye, 233 Cal. App. 2d 143, 149, 43 Cal. Rptr. 231, 236 (1965). See also note 41 infra and acconpanying text.

35 E.g., United States v. Baysden, 326 F.2d 629 (4th Cir. 1964); Kennedy v. United States, 249 F.2d 257 (5th Cir. 1957), cert. denied, 359 U.S. 994 (1959); Julian v. United States, 236 F.2d 155 (6th Cir. 1956); Patten v. State, 50 Ariz. 32, 68 P.2d 669 (1939); Jones v. State, 221 Md. 141, 156 A.2d 421 (1959); Bullock v. Harpole, 233 Miss. 486, 102 So. 2d 687 (1958); State v. Leckis, 79 N.J. Super. 479, 192 A.2d 161 (1963); Ex parte Hull, 91 Okla. Crim. 11, 215 P.2d 587 (1950). At least three states, Massachusetts, West Virginia, and North Carolina, now require that a written waiver of the right to counsel be executed by the defendant. See Silverstein, The Continuing Impact of Gideon v. Wainwright on the States, 51 A.B.A.J. 1023 (1965). But see Archer v. Clarke, 202 Ga. 229, 42 S.E.2d 924 (1947) (plea of guilty accepted over defendant's protest).

${ }^{36}$ Poe v. United States, 233 F. Supp. 173, 176 (D.D.C. 1964) (decision to testify); accord, United States ex rel. Goldsby v. Harpole, 263 F.2d 71 (5th Cir.), cert. denied, 361 U.S. 838, 850 (1959) (waiver of a fairly constituted petit jury); People v. Blye, 233 Cal. App. 2d 143, 43 Cal. Rptr. 231 (1965) (withdraw plea of not guilty); cf. Gideon v. Wainwright, 372 U.S. 335 (1963); Palko v. Connecticut, 302 U.S. 319 (1937).

37 Poe v. United States, supra note 36 , at 176.

38263 F.2d 71 (5th Cir.), cert. denied, 361 U.S. 838, 850 (1959).

39 Id. at 80 . 
identical circumstances and in the same case, Goldsby was held to his counsel's waiver of a timely challenge to the grand jury, and the court implied that the consequences of irregularities in the composition of that body were not so fundamental..$^{40}$

In general, an mcreasing number of courts have held that the entering of a plea ${ }^{41}$ the waiver of a right to a jury trial, ${ }^{42}$ and the decision not to appea ${ }^{43}$ require some personal participation by the accused. Courts disagree, however, as to the "fundamental nature" of other waivers: for example, the choice that defendant shall testify, ${ }^{44}$ submission of the case on the preliminary transcript, ${ }^{45}$ and the objection to the introduction of illegally obtamed evidence. ${ }^{46}$ Most often the concept of essential fairness governs collateral review; ${ }^{47}$ and this inherently nebulous standard has thus produced hittle uniformity among jurisdictions.

However, the majority of courts have accepted the position that, with the exception of fundamental rights and in the absence of "exceptional circumstances,"48 an attorney's waiver will be binding on the defendant. ${ }^{49}$ This presumption ${ }^{50}$ has made appellate or collateral attack of counsel's waiver an almost impossible task, since most courts have been reluctant to increase the number of "fundamental" rights and

40 Id. at 80,84 .

41 "In such case the requisite elements should appear from the defendant's own recital ... ." People v. Serrano, 15 IN.Y.2d 304, 308, 258 N.Y.S.2d 386, 388, 206 N.E.2d 330, 332 (1965); accord, United States v. Diggs, 304 F.2d 929 (6th Cir. 1962); Cooke v. Swope, 28 F. Supp. 492 (W.D. Wash. 1939); People v. Blye, 233 Cal. App. 2d 143, 149, 43 Cal. Rptr. 231, 236 (1965); In re Martinez, 52 Cal. 2d 808, 345 P.2d 449 (1959); Johnson v. Commonwealth, $254 \mathrm{Ky}$. 775, 72 S.W.2d 472 (1934). Several statutes also require some degree of personal participation. E.g., Fed. R. CrRM. P. 11; Car. PenaI, Code $\$ 1018$.

42 E.g., United States ex rel. Goldsby v. Harpole, 263 F.2d 71 (5th Cir.), cert. denied, 361 U.S. 838, 850 (1959); People v. Blye, 233 Cal. App. 2d 143, 149, 43 Cal. Rptr. 231, 236 (1965). See, e.g., Mrch. Stat. Ans. § 28.856 (1954).

43 Fay v. Noia, 372 U.S. 391 (1963).

44 Compare Poe v. United States, 233 F. Supp. 173 (D.D.C. 1964), with Tompsett v. Ohio, 146 F.2d 95 (6th Cir. 1944), cert. denied, 324 U.S. 869 (1945).

45 Compare People v. Montoya, 235 Cal, App. 2d 789, 45 Cal. Rptr. 572 (1965), with Wilson v. Gray, 345 F.2d 282 (9th Cir.), cert. denied, 382 U.S. 919 (1965).

46 Compare State v. Mendes, 210 A.2d 50 (R.I. 1.965), with United States ex rel. Reid v. Richmond, 295 F.2d 83 (2d Cir.), cert. denied, 368 U.S. 948 (1961).

47 Fay v. Noia, 372 U.S. 391, 438 (1963); accord, United States ex rel. Smith v. Baldi, 344 U.S. 561, 573 (1953) (Frankfurter, J., dissenting).

48 See note 181 infra and accompanying text.

49 E.g., Brown v. Allen, 344 U.S. 443,463 (1.953); Nelson v. State of California, 346 F.2d 73 (9th Cir. 1965); Wilson v. Gray, 345 F.2d 282 (9th Cir.), cert. denied, 382 U.S. 919 (1965); United States ex rel. Reid v. Richmond, 295 F.2d 83 (2d Cir.), cert. denied, 368 U.S. 948 (1961); Mitchell v. United States, 259 F.2d 787 (D.C. Cir.), cert. denied, 358 U.S. 850 (1958); United States ex rel. Kozicky v. Fay, 248 F.2d 520 (2d Cir. 1957), cert. denied, 356 U.S. 960 (1958).

50 See Moore v. Michigan, 355 U.S. 155, 161 (1957). See also cases cited at note 101 infra. 
have greatly expanded the concept of nonpersonal waiver to bind the defendant to his counsel's actions. In Wilson v. Gray ${ }^{51}$ the attorney, in defendant's presence but without his personal concurrence, stipulated that the matter be heard on the transcript of the preliminary hearing. The court found that there had been an effective waiver of the rights of confrontation and cross examination, ${ }^{52}$ even though the transcript contained sucl overwhelming evidence against the accused that the stipulation could be considered tantamount to a plea of guilty. ${ }^{53}$

The rationale behind this reluctance to find the right waived fundamental or the circumstances exceptional seems to rest upon considerations of administrative efficiency and effective representation.

\section{B. Opportunity for Consultation}

The principal ground by whicl courts lave sought to justify the binding effects of a nonpersonal waiver is the theory that "counsel must be the manager of the lawsuit ...." ${ }^{\prime 4}$ This pragmatic concept of control of courtroom procedure is in several ways a sensible one.

First, judicial efficiency frequently demands that one person manage the lawsuit for each opposing party. Confusion is prevented, and each side is forced to a single position on eacl issue. Furthermore, when the attorney is able to argue the case and make oral objections without having to consult his client, costly delays are prevented, and the jury is not distracted.

Second, many attorneys might hesitate to participate in a criminal case if they were to be subjected to continuous compulsory consultation during the heat of a courtroom battle. ${ }^{55}$

Perhaps the most important reason for the courts' hesitance in requiring a personal waiver is the fact that when decisions are made by the defendant, he is likely to do himself more harm than good. ${ }^{56}$ Barring indifference or incompetence, ${ }^{57}$ the attorney's decision is bound to be based on a sounder understanding of the strategy and procedure involved. Indeed, the very concept of personal waiver is predicated on the often erroneous assumption that the client can understand the implications and

51345 F.2d 282 (9th Cir.), cert. denied, 382 U.S. 919 (1965).

52 Id. at 287-88.

53 Gray v. Wilson, 230 F. Supp. 860, 862 (N.D. Cal. 1964), rev'd, 345 F.2d 282 (9th Cir.), cert. denied, 382 U.S. 919 (1965). Cf. Poe v. United States, 233 F. Supp. 173, 177 (D.D.C. 1964).

54 Nelson v. State of California, 346 F.2d 73, 81 (9th Cir. 1965).

${ }^{65}$ See Mitchell v. United States, 259 F.2d 787, 790 (D.C. Cir.), cert. denied, 358 U.S. 850 (1958).

vo See Nelson v. State of California, 346 F.2d 73, 81 (9th Cir. 1965).

57 See note 100 infro and accompanying text. 
ramifications of the decisions he has to make. For example, it is difficult to conceive of the average defendant making an "intelligent and knowing" waiver of his right to challenge an illegally constituted jury ${ }^{58}$ or of his privilege against self-incrimination: ${ }^{59}$ Without some legal background, few persons could understand the consequences of such a relinquishment in terms of cross examination, impeachment, jury effect, character evidence, and prior criminal record. Most defendants merely wish to "tell my side of the story" and are oblivious to the procedural consequences of such a step. Counsel may have the duty "to present to him the relevant information on which he may make an intelligent decision, and this advice may make some impression; but it is doubtful that it will normally result in the degree of "understanding" which the Supreme Court assumed in Fay v. Noia. ${ }^{01}$ Furthermore, recent cases involving voluntary statements made personally by the defendant ${ }^{62}$ may indicate that the courts are unwilling to let the accused make an unenlightened, though free, choice. ${ }^{63}$ Indeed, the court in Rhay v. Browder ${ }^{64}$ states that strict adherence to a rule requiring personal participation and decision would greatly weaken the sixth amendment riglt to effective counsel. ${ }^{65}$ Certainly, in most cases competent counsel can make a far more intelligent decision than the typical defendant who is ignorant of his legal rights; therefore, the most effective defense is frequently the one in which the attorney is relatively free from constant supervision by his client.

58 See Whitus v. Balkcom, 333 F.2d 496, 502-03 (5th Cir.), cert. denied, 379 U.S. 931 (1964). United States ex rel. Goldsby v. Harpole, 263 F.2d 71, 83 (5th Cir.), cert. denied, 361 U.S. 838, 850 (1959), however, required that this decision be made personally by the defendant in a capital case unless the record affirmatively shows that counsel thought such waiver was the best alternative open to his client.

69 Poe v. United States, 233 F. Supp. 173, 176 (D.D.C. 1964) held that the decision to have the accused testify was a personal one.

60 Ibid.

61372 U.S. at 439 . The plea of guilty and the decision to appeal can probably be understood by most defendants. The consequences of other waivers, however, are not so easily comprehended.

62 E.g., People v. Dorado, 62 Cal. 2d 338, 398 P.2d 361, 42 Cal. Rptr. 169, cert. denied, 381 U.S. 937 (1965).

${ }^{63}$ A recent Cahifornia case, People v. Shields, 232 Cal. App. 2d 716, 43 Cal. Rptr. 188 (1965), stated that, " '[T] he trial court is duty bound to determine whether he [defendant] is making a competent, intelligent and complete waiver of his constitutionally guaranteed right to be represented by counsel. .. . It is apparent from defendant's general denieanor and his response to the court's questions that be could not nake a competent, intelligent and complete waiver of his right to counsel, and that he was not competent to represent himself at the trial." Id. at 722; 43 Cal. Rptr. at 192-93. See, e.g., FED. R. CRrM. P. 11; Cat. Penal Code $\$ 1018$.

64342 F.2d 345 (9th Cir. 1965).

65 Id. at 349; accord, Nelson v. State of Cahifornia, 346 F.2d 73, 81 (9th Cir. 1965). 
These justifications for the attorney's control-and thus for nonpersonal waiver-do not cover every courtroom situation, however. There would be little loss of either judicial or advocate efficiency if the defendant were allowed to participate in those decisions made by the defense at a time when there was a definite opportunity for consultation between counsel and client. Clearly, the area in which this distinction would have the greatest effect would be that of pre-trial motions and decisions. The reasons set forth for denying the requirement of personal waiver at the trial stage are largely vitiated when taken in the context of pre-trial procedures. For instance, when a trial on the transcript of the preliminary hearing is to be stipulated, ${ }^{66}$ very hittle time would be lost if the court were to assure itself either that the defendant appreciated the consequences of his waiver or that he was aware of the right in question and would abide by his attorney's judgment in the matter. No jury confusion would result; and judicial efficiency would be promoted, in that such affirmative participation by the accused would prevent a retrial resulting from a subsequent collateral attack on the ground that no affirmative waiver was effected or that the waiver was not personal. ${ }^{67}$

Furthermore, the adverse consequences, in terms of effective defense, of the accused's personal participation are also somewhat neutralized when considered at the pre-trial stage. Unhike the trial itself when the attorney is in active control of the defense argument, his functions at the prehminary stages are largely advisory: Primarily he is present to inform the client of his rights and to guide him through the maze of pre-trial procedure. There is no jury to affect, no consequences relating to cross examination, and no possibility of distracting counsel from the presentation of the case. Moreover, the rights most often waived at pre-trial-for example, the right to a trial or the right to a properly constituted juryare closely related to the accused's plea of guilty, which, in many jurisdictions, requires defendant's personal participation. ${ }^{68}$ Also, a more extensive explanation can be given to the defendant at this time. He can thus make a more intelligent decision; or if this is beyond his abilities, the court will have a greater opportunity to observe his incapacity ${ }^{69}$ and to determine that he was unable to make the intelligent and understanding waiver required by Johnson and Fay. The trial court would therefore assure itself that there had been participation by the defendant, ${ }^{70}$ that

${ }^{66}$ As in Wilson v. Gray, 345 F.2d 282 (9th Cir.), cert. denied, 382 U.S. 919 (1965).

${ }^{67}$ See Wood v. United States, 128 F.2d 265, 277 (D.C. Cir. 1942). But see People v. Kirchner, 233 Cal. App. 2d 83, 89, 43 Cal. Rptr. 218, 223 (1965).

68 Cf. Brookhart v. Janis, 86 Sup. Ct. 1245 (1966); See also note 41 supre.

60 Such observations were made at pre-trial in People v. Shields, 232 Cal. App. 2d 716, 43 Cal. Rptr. 188 (1965). See also note 61 supra.

70 The ideal of a personal waiver, in which defendant either made the decision himself 
the waiver was deliberate, and that the trial result would not be successfully attacked on those grounds.

Most courts, however, have not distinguished between pre-trial and trial waivers ${ }^{71}$ in requiring the accused's personal participation. They have instead tried to weigl the exceptional circumstances in which counsel's decision was taken ${ }^{72}$ or the importance of the right waived. ${ }^{73}$ But by making use of this pre-trial distinction-and the differences in opportunities for consultation-courts could avoid having to draw such fine lines as those between "fundamental" and "trial" decisions, ${ }^{74}$ at least at the pre-trial stage. Thus, when the exigencies of litigation demand of the attorney the quick decisions essential to an effective defense, the defendant cannot expect to be consulted. ${ }^{75}$ When, however, strategy, efficiency, or opportunity cannot possibly justify the lack of a personal waiver, there seems to be little justification for binding the defendant to a relinquishment of constitutional rights to which he has never consented.

\section{Attorney's Trial Waiver}

The "opportunity for consultation" standard is far more difficult to apply and to justify after the trial is in progress. It is then that counsel must take active command of the defense and make on-the-spot tactical decisions on behalf of his client. ${ }^{78}$ There is rarely an "opportunity" to

or specifically authorized his attorney to do so, was emphasized in Fay v. Noia, 372 U.S. 391, 438 (1963), and Whitus v. Balkcom, 333 F.2d 496, 502 (5th Cir.), cert. denied, 379 U.S. 931 (1964). The courts that have required defendant's participation have imphed that the accused should decide his own fate, thereby exercising a greater degree of control over factors ultimately affecting only his future. In this sense, courts have recognized that the "exercise of free will and judgment" is an important element in this area. People v. Gilbert, $25 \mathrm{Cal} .2 \mathrm{~d}$ 422, 443, 154 P.2d 658, 668 (1944). Furthermore, this concept was reaffirmed in People v. Blye, 233 Cal. App. 2d 143, 43 Cal. Rptr. 231 (1965), which stated that if the accused makes a timely demand to take the stand contrary to the advice given by his counsel, he has a right to present his defense in this manner, even if fatal to his chances of acquittal. Id. at 235; accord, Moss v. Hunter, 167 F.2d 683 (10th Cir.), cert. denied, 334 U.S. 860 (1948). This proposition of ultimate free will and decision, however, is far from totally accepted by all courts. Recent cases stressing the right to counsel also seem to imply that the defendant will not be allowed to waive a right or make a statement which would be highly prejudicial to a plea of not guilty. See Escobedo v. Illinois, 378 U.S. 478 (1964); Nelson v. State of California, 346 F.2d 73, 81 (9th Cir. 1965).

71 See, e.g., Wilson v. Gray, 345 F.2d 282 (9th Cir.), cert. denied, 382 U.S. 919 (1965).

72 See note 181 infra and accompanying text.

73 See note 34 supra and accompanying text.

74 E.g., Poe v. United States, 233 F. Supp. 173, 176 (D.D.C. 1964).

${ }^{75}$ Wilson v. Gray, 345 F.2d 282, 286 (9th Cir.), cert. denied, 382 U.S. 919 (1965); Poe v. United States, 233 F. Supp. 173, 176 (D.D.C. 1964). But see note 85 infra.

76 "Trial counsel must make many decisions of an almost infinite variety in the course of a criminal trial ... . Bad judgment, or even good but erroneous judgment, may result in adverse effects. These are simple facts of trial; they are not justiciable issues." Mitchell v. 
interrupt the proceedings to ask the defendant if he acquiesces in the decision of his counsel. Indeed, it would be impossible to do so where counsel effects a waiver by omission, unless the judge were to play an active role in the defense by calling this to the defendant's attention. ${ }^{77}$ Furthermore, it would greatly complicate trial procedure and make the defense counsel far less efficient. ${ }^{78}$

The relationship between Fay and Henry is crucial to a proper understanding of the binding effect of an attorney's trial waiver. Even though Fay dealt with a post-trial waiver, the Court strongly emphasized that "at all events we wish it clearly understood that the standard here put forth [deliberate bypass] depends on the considered choice of the petitioner. . . . A choice made by counsel not participated in by the petitioner does not automatically bar relief."779 The Court, in stressing the importance of defendant's participation, made no distinction among pre-trial, trial, and post-trial waivers, and seemed to imply that the standard would apply throughout. ${ }^{80}$

On the other hand, the Court in Henry stated that, "If either [strategic] reason inotivated the action of petitioner's counsel, and their plans backfired, counsel's deliberate choice of the strategy would amount to a waiver bimding on petitioner and would preclude him from a decision on the merits of his federal claim either in the state courts or liere."11

If these two statements are inconsistent, then Mr. Justice Brennan, who wrote both opinions in the span of two years, has retreated from his original position in Fay. The court of appeals in Nelson v. State of California ${ }^{82}$ seemed to think that such an inconsistency did exist:

We think that Henry limits Fay v. Noia at least to this extentthat it stands for the proposition that counsel's decision, although made "without prior consultation with an accused," to by-pass the contemporaneous-objection rule as part of trial strategy, will nevertheless "preclude the accused from asserting constitutional claims".... Thus the broad language in Fay, to the effeot that the decision (there,

United States, 259 F.2d 787, 792 (D.C. Cir.), cert. deried, 358 U.S. 850 (1958); accord, Commonwealth ex rel. Adderly v. Myers, $418 \mathrm{~Pa} .366,211$ A.2d 481 (1965).

77 Even then the judge must first recognize the waiver by omission. Moreover, it is generally recognized that the court should not act as an assaciate counsel. See, e.g., Mitchell v. United States, stipra note 76, at 793; Woodell v. State, 223 Md. 89, 95, 162 A.2d 468, 472 (1960).

78 See note 64 supra and accompanying text.

79372 U.S. at 439.

80 "But a forfeiture of remedies does not legitimatize the unconstitutional conduct by which his conviction was procured." Id. at 428. This interpretation of Fay-of applying the requirement of personal waiver to trial decisions-was given in State v. Mendes, 210 A.2d 50, 55 (R.I. 1965).

81379 U.S. at 451.

82346 F.2d 73 (9th Cir. 1965). 
a decision not to appeal) must be the choice of the petitioner, and that a choice made by counsel, not participated in by petitioner, does not automatically bar relief, does not here apply. ${ }^{83}$

It is questionable, however, that the Supreme Court intended to carry the Fay statement to the extreme that all trial decisions must be personally participated in by defendant. Indeed, the very fact which Nelson relegates to a parenthetical expression is the important distinction between the two cases: Fay dealt with a waiver of the right to appeal; whereas the issue in Henry was a waiver of a strategic device of courtroom litigation, the objection to the introduction of illegally obtained evidence. A relinquishment of the former right is as fundamental as a plea of guilty and is calculated to result in the continued incarceration of the defendant. Few courts would permit an attorney to make such a decision without the knowing and intelligent participation of his chent. ${ }^{84}$ The waiver of the right to object to the introduction of evidence, however, has normally been within the discretion of the attorney, ${ }^{86}$ since it is an ordinary strategic decision inade during the heat of the trial. The distinction is, in effect, impliedly identical to the requirement of a personal waiver of the right to a trial: ${ }^{88}$ When the action is tantamount to an acceptance of defendant's guilt, that act must be the result of his personal decision. ${ }^{87}$ When, however, the action is a strategic maneuver attempting to effect the accused's ultimate acquittal, such a trial decision inay be made by counsel, and inere lack of success is no basis for reversal. ${ }^{88}$ This tactical choice will bind defendant, unless the right waived by the attorney was so essential to a fair presentation of his client's claims that its abandonment was totally inconsistent with the latter's plea

\footnotetext{
83 Id. at 81 . See, however, note 89 infra.

84 E.g., Fay v. Noia, 372 U.S. 391, 438 (1963); Johnson v. Zerbst, 304 U.S. 458 (1938). See also cases cited at note 35 supra.

85 Mitchell v. United States, 259 F.2d 787, 792 (D.C. Cir.), cert. denied, 358 U.S. 850 (1958). This position is accepted by the great majority of courts. However, in response to the Supreme Court's emphasis of personal relinquishment in Fay, some courts have extended the requirement of personal waiver and consultation even to trial decisions made by the attorney. For example, in State v. Mendes, 210 A.2d 50 (R.I. 1965), the Rhode Island court quashed a verdict of guilty and held that there had been no effective waiver of the right to exclude an illegally obtained confession, even though defendant's attorney expressly agreed to the admission of the statement. "There is no merit in the state's contention that there was a valid waiver by his counsel's express statement that he had no objection to its admission. There is nothing in the record indicating that defendant participated in his counsel's decision in this matter. Absent such participation, defendant's constitutional rights cannot be waived." Id. at 55. This approach represents a small minority of courts to date.

86 See United States ex rel. Goldsby v. Harpole, 263 F.2d 71, 83 (5th Cir.), cert. denied, 361 U.S. 838,850 (1959).

87 See Fay v. Noia, 372 U.S. 391,439 (1963). See also cases cited at note 41 supra.

88 Mitchell v. United States, 259 F.2d 787 (D.C. Cir.), cert. denied, 358 U.S. 850 (1958).
} 
of not guilty. ${ }^{89}$ This may be the ultimate factor in a court's determination that a relinquishment was fundamental and therefore had to be personal.

There is further reason to believe that the Henry Court did not intend to retreat from the personal participation doctrines of Fay v. Noia. As previously stated, the least Henry did was to reinforce the implied distinction between fundamental and strategic waivers in the area of necessity of personal waiver. However, the decision went much further in another context: It extended Fay's "deliberate bypass" test to the area of counsel's strategic decisions. The Fay Court spoke in terms of the defendant's understanding and knowing waiver, ${ }^{90}$ since that case dealt with a personal waiver. Henry, however, carries the application of the standard even further. By remanding the case on the factual issue of whether the attorney knowingly, intelligently, and dehberately waived the right to object, ${ }^{91}$ the Court insisted that in some cases even those waivers which counsel may effect without the defendant's participation must be made intentionally. ${ }^{92}$ In other words, Fay had previously established the fact that the defendant himself could not waive his rights, unless he understood those rights and intended to relinquish them. Now the same standard has been applied to the attorney.

The consequences of this interpretation are entirely consistent with the goal of protecting the accused's constitutional rights. The logical extension of the substantive guarantee against the use of involuntary confessions, ${ }^{93}$ for example, is the procedural assurance that this fundamental right will not be waived inadvertently by either counsel or defendant. ${ }^{94}$ If a nonpersonal waiver is allowed to extinguish the accused's

80 Brookhart v. Janis, 86 Sup. Ct. 1245, 1248-49 (1966): "Our question therefore narrows down to whether counsel has power to enter a plea which is inconsistent with his client's expressed desire and thereby waive his client's constitutional right to plead not guilty and have a trial in which he can confront and cross-examine the witnesses against him. We hold that the constitutional rights of a defendant cannot be waived by his counsel under such circumstances. . . Nothing in Henry, however, can possibly support a contention that counsel for defendant can override his client's desire expressed in open court to plead not guilty and enter in the name of his client another plea-whatever the labelwhich would shut off the defendant's constitutional right to confront and cross-examine the witnesses against him which he would have an opportunity to do under a plea of not guilty. Since we hold that petitioner neither personally waived his right nor acquiesced in his lawyer's attempted waiver, the judgment . . . is reversed . . ." Accord, Brubaker v. Dickson, 310 F.2d 30, 38 (9th Cir. 1962), cert. denied, 372 U.S. 978 (1963).

90372 U.S. at 439 .

91379 U.S. at $451-53$.

92 Brubaker v. Dickson, 310 F.2d 30, 38 (9th Cir. 1962), cert. denied, 372 U.S. 978 (1963), also suggests such a standard.

${ }^{93}$ E.g., Spano v. New York, 360 U.S. 315 (1959); McNabb v. United States, 318 U.S. 332 (1943).

94 E.g., Henry v. Mississippi, 379 U.S. 443 (1965); Fay v. Noia, 372 U.S. 391 (1963); Whitus v. Balkcom, 333 F.2d 496 (5th Cir.), cert. denied,-379 U.S. 931 (1964). 
constitutional rights, federal courts should require that the abandonment at least be intentional. Previously, such intent was not required. ${ }^{05}$ The Henry decision, however, seems to impose this requirement of intent for counsel's waiver and does so at the trial stage. ${ }^{06}$ The justification for this requirement is that if the accused must make a knowing and intelligent waiver, his attorney should be held to the same standard, since either party's waiver may substantially affect the outcome of the trial.

It is clear, however, that such a standard cannot be applied universally, because the client is not entitled to a defense free from all error. ${ }^{07}$ Therefore, the Henry requirement of intentional waiver must be limited in some way to prevent reversal whenever defense counsel relinquishes an insignificant right or commits a harmless error. The Henry Court impliedly restricts this standard to the same types of waiver which the Fay Court required to be personal: When the right is so fundamental as to be determinative of the result of the trial, it must be personally waived; ${ }^{08}$ or, if that is not possible because of the exigencies of trial procedure and efficiency, then counsel's waiver must be deliberate. ${ }^{00}$ The effect of this extension of the $F a y$ rationale is to require that the attorney's waiver of an essential protection at least be an intentional one if it is to foreclose defendant from thereafter asserting that right.

\section{II}

\section{PROBLEMS OF INCOMPETENCE}

The problems inherent in an analysis of the binding effect of an attorney's waiver are inseparable from the questions of incompetent counsel. It has long been settled that the sixth amendment right to counsel conveys a right to "effective" counsel. ${ }^{100}$ However, courts have tended to raise a strong presumption of competence ${ }^{101}$ and have generally held that "the term 'effective' has been used by the Supreme Court to describe a procedural requirement, as contrasted with a standard of

05 See, e.g., Daniels v. Allen, reported with Brown v. Allen, 344 U.S. 443 (1953).

06379 U.S. at $450-52$.

07 E.g., Rivera v. United States, 318 F.2d 606, 608 (9th Cir. 1963). See also cases cited at note 103 infra.

98379 U.S. at $450-51$. See also cases cited at note 41 supra.

$09 \mathrm{Id}$. at 451 . The exception for harmless error, of course, encompasses the doctrine of waiver. Fahy v. Connecticut, 375 U.S. 85 (1963).

100 Powell v. Alabama, 287 U.S. 45 (1932).

101 E.g., United States ex rel. Feeley v. Ragen, 166 F.2d 976 (7th Cir. 1948); Beckett v. Hudspeth, 131 F.2d 195 (10th Cir. 1942); Duval v. Humphrey, 83 F. Supp. 457 (M.D. Pa. 1949); People v. Harrison, 46 Cal. App. 2d 779, 117 P.2d 19 (1941). Courts also make the presumption that an attorney who is admitted to practice before the highest court of the state is competent. Umited States ex rel. Weber v. Ragen, 176 F.2d 579 (7th Cir.), cert. denied, 338 U.S. 809 (1949). 
skill."102 All courts have thus been hesitant to review counsel's performance and have refused to equate "effective assistance" with "flawless defense. ${ }^{1103}$ Hence, the attorney's inexperience, ${ }^{104}$ lack of preparation, ${ }^{105}$ unfamiliarity with procedure, ${ }^{106}$ and unwise advice ${ }^{107}$ have all been held to be insufficient grounds for reversal of an otherwise sound conviction.

There are several bases usually cited in support of this position. The agency doctrine is a recurrent theme throughout the various discussions of incompetency. ${ }^{108} \mathrm{~A}$ similar basis for binding defendant to the incompetent acts of his attorney is found in the concept of ratification by silence: When defendant does not make his objection to such acts known at the trial, he is deemed to have ratified those decisions and cannot then seek reversal. ${ }^{109}$ Finally, courts have often expressed the fear that counsel could deliberately fail to perform an essential function of the defense, so that the accused would have a bikely ground for reversal should he be convicted. ${ }^{110}$ In short, courts have generally held that "absence of effective

102 Mitchell v. United States, 259 F.2d 787, 790 (D.C. Cir.), cert. denied, 358 U.S. 850 (1958).

103 Ibid.; accord, Rivera v. United States, 318 F.2d 606 (9th Cir. 1963); O'Malley v. United States, 285 F.2d 733 (6th Cir. 1961); Tompsett v. Ohio, 146 F.2d 95 (6th Cir. 1944), cert. denied, 324 U.S. 869 (1945); United States v. Cariola, 211 F. Supp. 423 (D.N.J. 1962), aff'd, 323 F.2d 180 (3d Cir. 1963); United States ex rel. Koffel v. Myers, 167 F. Supp. 510 (E.D. Pa. 1958) ; People v. Rodriguez, 143 Cal. App. 2d 506, 299 P.2d 1057 (1956).

104 E.g., Anderson v. Bannan, 250 F.2d 654 (6th Cir. 1958); Farrell v. Lanagan, 166 F.2d 845 (1st Cir.), cert. denied, 334 U.S. 853 (1948); United States ex rel. Koffel v. Myers, 167 F. Supp. 510 (D.C. Pa. 1958). But see People v. Tbarra, 60 Cal. 2d 460, 386 P.2d 487, 34 Cal. Rptr. 863 (1963).

105 E.g., Goforth v. United States, 314 F.2d 868 (10th Cir. 1963); Adams v. United States, 222 F.2d 45 (D.C. Cir. 1955); Tompsett v. Ohio, 146 F.2d 95 (6th Cir. 1944), cert. denied, 324 U.S. 869 (1945) ; United States v. Sumpter, 111 F. Supp. 507 (S.D.N.Y. 1953), 228 F.2d 290 (2d Cir. 1955). But see Brubaker v. Dickson, 310 F.2d 30 (9th Cir. 1962), cert. denied, 372 U.S. 978 (1963); Jones v. Huff, 152 F.2d 14 (D.C. Cir. 1945).

108 E.g., State v. Miller, 16 N.J. Super. 251, 84 A.2d 459 (1951), cert. denied, 342 U.S. 934 (1952). A very liberal approach was taken by the Mississippi Supreme Court when it refused to bind Henry to a waiver made by non-local counsel, who was unfamiliar with local procedure. When, however, a Suggestion of Error was filed by the state in which it was proved that defense counsel had been assisted by a local attorney, the Mississippi Supreme Court withdrew its first opinion and substituted an identical one, the only differences being the result and the discussion of counsel's waiver. See Henry v. Mississippi, 379 U.S. $443,445-46$ (1965).

107 E.g., Johnson v. United States, 267 F.2d 813 (9th Cir.), cert. denied, 361 U.S. 889 (1959); Thomson v. Huff, 149 F.2d 842 (D.C. Cir. 1945); People v. Gonzalez, 15 Misc. 2d 438, 182 N.Y.S. 2d 142 (Gen. Sess. 1957); People v. Elmer, 112 Cal. App. 2d 415, 246 P.2d 60 (1952); In re Flowers, 71 Okla. Crim. 330, 111 P.2d 509 (1941).

108 E.g., Tompsett v. Ohio, 146 F.2d 95, 98 (6th Cir. 1944), cert. denied, 324 U.S. 869 (1945). See also cases cited at note 116 infra.

109 E.g., Kennedy v. United States, 259 F.2d 883, 885 (5th Cir. 1958), cert. denied, 359 U.S. 994 (1959); Tompsett v. Ohio, supra note 108, at 98.

110 E.g., People v. Mitchell, 411 Ill. 407, 104 N.E.2d 285, cert. denied, 343 U.S. 969 
representation by counsel must be strictly construed,"111 and "mere incompetence" is not sufficient grounds to find such a deficiency.

\section{A. Agency and Incompetence}

The inadequacy of the general agency approach to the problem of incompetence can be seen by examining the case of Tompsett $v$. Ohio ${ }^{112}$ in detail. Despite a long list of inexplicable "waivers"113 by his retained counsel, the federal court denied Tompsett relief, holding that those omissions, though perhaps incompetent, were imputed to the client.114 The court qualified its holding, however, by saying that this rule would not apply where it appeared that the defendant was too ignorant of his procedural rights to coniplain to the court. ${ }^{115}$

The doctrinal and practical difficulties in applying agency principles to the criminal trial have never been adequately answered by those courts which accept the Tompsett approach. ${ }^{110}$ In commercial transactions the principal is bound by the errors of his agent, so that third parties will be protected: ${ }^{117}$ However, as discussed below, agency doctrine is not applicable to the criminal trial in which the interests of the accused are given more weight than the third party in commercial dealings. And, while the rules of agency may provide a basis for finality in litigation, the mere existence of the attorney-chent relationship is no mherent justification for binding the accused to a waiver which results in his incarceration. Moreover, the problems evident in ascertaining when the client has or has not authorized a particular decision-or whether such authorization is even necessary-demonstrate the unnecessary complexities which sucl a standard introduces.

(1952). This fear should now be obviated with the use of the deliberate bypass standard. See note 125 infra and accompanying text.

111 Diggs v. Welch, 148 F.2d 667, 670 (D.C. Cir.), cert. denied, 325 U.S. 889 (1945); accord, Dayton v. United States, 319 F.2d 742 (D.C. Cir.), cert. denied, 375 U.S. 947 (1963).

112146 F.2d 95 (6th Cir. 1944), cert. denied, 324 U.S. 869 (1945).

113 His attomey's "waivers" and omissions consisted of failing to attend the prelininary hearing, to bring out the fact that descriptions of the robber by prosecution witnesses did not include the fact that defendant had a marked himp from polio, to cross examine those witnesses, to subpena witnesses that defendant said would corroborate his alibi, and to nove (despite defendant's urging) for a separation of witnesses. Furthermore, be neglected to file a timely appeal and advised his client to waive a jury trial because he thought the judge would be lenient. $I d$. at 97-98.

114 Id. at 98 .

115 Ibid.

110 E.g., Evans v. Hunter, 94 F. Supp. 837 (D. Kan. 1951) ; Rice v. Davis, 366 S.W.2d

153 (Ky. 1963); Jones v. Balkcom, 210 Ga. 262, 79 S.J.2d 1 (1953); Miller v. Hudspeth, 164 Kan. 688, 192 P.2d 147 (1948).

117 E.g., Merchants' Bank v. State Bank, 77 U.S. (10 Wall.) 604, 646 (1870). 
When the factor of incompetence is added, the defendant's liability for counsel's relinquislment of his federal protections becomes even more difficult to accept. The agency must then cover not only those acts intended to effect defendant's acquittal, but also those waivers which were either unintelligent or inadvertent. To this extent, the often fictional "apparent authority" has been expanded to encompass acts which the accused never intended to "authorize," even as part of trial strategy. It seems clear that the sixth amendment right to effective assistance of counsel should not rest on this type of fictitious assumption.

The imputed acts doctrine is even more difficult to sustain in light of the Fay and Henry cases. While Fay emphasized the importance of a knowing personal waiver, ${ }^{118}$ Tompsett's counsel ignored his client's frequent demands to correct the many omissions. ${ }^{119}$ Such a defense hardly meets the requirement that, a valid waiver "depends on the considered choice of the petitioner." ${ }^{\text {"120 }}$ This personal element was entirely missing in Tompsett's case; and the court, in effect, used the agency rationale instead. However, one important purpose of the Fay decision was to distinguish such personal waiver from that of the attorney; ${ }^{121}$ and the intent implied in that decision was to limit the agency doctrine in favor of an expanded notion of personal waiver. ${ }^{122}$ Furthermore, even if some of the Tompsett waivers were "tactical" and did not require consultation and defendant's personal approval, ${ }^{123}$ it could hardly be said that the attorney made the intentional and intelligent abandonment of his chient's rights which Henry seems to require. ${ }^{124}$ Counsel failed, for example, to cross examine the prosecution witnesses on the discrepancy between their description of the thief and defendant's marked polio limp. This waiver bears no resemblance to the "deliberate choice of strategy" discussed in the Henry decision: ${ }^{125}$ The omission could not possibly be characterized as a deliberate attempt to effect defendant's acquittal, since these factors were essential elements of the defense; and the precise intent of the Henry Court was that this type of glaring, inadvertent default should not foreclose federal review. Unless counsel's purported waiver was a

118372 U.S. at 439.

119146 F.2d at 97. The court emphasized that the defendant did not make his objections known to the trial court at the time and therefore could not complain later unless he could prove he was ignorant of trial procedure. $I d$. at 98 .

120 Fay v. Noia, 372 U.S. 391, 439 (1963). Cf., Brookhart v. Janis, 86 Sup. Ct. 1245 (1966).

121 This rationale is made even more exphicit in Whitus v. Ballscom, 333 F.2d 496, 502-03 (5th Cir.), cert. denied, 379 U.S. 931 (1964).

122372 U.S. at 438-39.

123 See note 85 supre and accompanying text.

124 See note 91 supra and accompanying text.

125379 U.S. at $451-52$. 
deliberate part of trial strategy, a federal court would have the discretionary power to find "the procedural default ineffective ..." In26 If the Henry Court had agreed with the prior use of agency principles to impute incompetent or unintentional omissions to the defendant, there would have been no need to remand for a factual finding of "deliberate waiver," simce it is clear that Henry's attorneys failed to comply with Mississippi's contemporaneous objection rule. Implicit in this result is the proposition that agency doctrine is no substitute for the element of intent in the waiver of essential rights.

An equally important phase of the Tompsett case was the requirement that the defendant promptly make known to the trial court any objections he may have had to his counsel's decisions. ${ }^{127}$ Otherwise, he would be deemed to have adopted the attorney's course of action. ${ }^{128}$ The court stated, however, that it would refuse to apply this rule where it was clear that the defendant was "ignorant of his rights and unacquainted with the course of proceedings in criminal cases." ${ }^{220}$

The necessity for the qualification in the case of the ignorant defendant is apparent: A chent who had no knowledge of his rights or of proper procedure could hardly be forced to make an objection when he did not realize that his rights had been waived or did not know that he was permitted to so object..$^{130}$ However, by admitting this necessary exception, the court rejected the very agency principles upon which its general rule was based. If the attorney is not an agent for the ignorant defendant, there is no justifiable reason to bind the "normal" defendant by this fiction. The inconsistency is especially evident in light of the fact that the agency principles, which were first applied to the attorney-client relationship in order to legitimatize the authority counsel had to manage a suit for lis legally ignorant client, are now rejected because of the latter's ignorance. Thus, in denying its application to the uninformed defendant,

$120 I d$. at 452 (direct review by the United States Supreme Court); accord, Fay v. Noia, 372 U.S. 391, 438-39 (1963) (collateral attack through federal babeas corpus).

127146 F.2d at 98 . Apparently, the Tompsett court felt that the accused should protest the actions of his counsel while the trial was in progress. Ibid. No analysis was made, however, of the confusion and disruption which would be likely to result.

128 Ibid.; accord, Kennedy v. United States, 259 F.2d 883, 885 (5th Cir. 1958), cert. denied, 359 U.S. 994 (1959).

129 Ibid. The qualification in full read: "The foregoing rule has no application when it is made to appear that the defendant is ignorant of lis rights and unacquainted with the course of proceedings in criminal cases. In that event if the attorney selected by such a defendant is so incompetent or dishonest or so improperly conducts defendant's case as to amount practically to no representation, the defendant is prejudiced and thereby deprived of a fair trial, and a court should grant relief by use of the writ of habeas corpus." Ibid. Tompsett, however, failed to make this showing and was held to the strict application of the general rule.

${ }^{130}$ Wood v. United States, 128 F.2d 265, 277 (D.C. Cir. 1942). 
the courts are forced to reject the doctrine of agency in the one case in which agency might make some sense because of the accused's total reliance. This circularity well illustrates the practical and theoretical difficulties which a court will encounter in relying on the theories of agency in a discussion of incompetent counsel.

Moreover, the Tompsett court's insistance on the ability of the "normally intelligent" defendant to recognize his attorney's incompetence and to vitiate that incompetence by timely objection to the trial court creates great practical difficulties. ${ }^{131}$ The defendant must either meet this obligation or overcome the heavy burden of showing that he was ignorant of his rights and of the procedures relevant thereto. ${ }^{132}$ The weight of this latter burden is frequently impossible to carry, even for the totally ignorant defendant, because the court will often presume sufficient knowledge merely because of the accused's previous criminal experience. ${ }^{133}$ These presumptions and obligations which are imposed on the defendant bear no resemblance to the realities of the courtroom experience. ${ }^{134} \mathrm{~A}$ California appellate court aptly noted:

[T] he defendant is usually not made aware of the possible incompetency of his counsel until the trial is at an end and until a third party points out the obvious deficiencies of the representation he has received. To hold a defendant to the obligation to object under such circumstances would be unrealistic. ${ }^{135}$

Furthermore, this obligation stands in sharp contrast to the proposition that counsel at all times has charge of the lawsuit. It "imputes to the defendant a knowledge of the law that common sense and experience indicate is not justified."136

\section{B. Recent Approaches to the Problems of Incompetence}

The courts" hesitance to vitiate a waiver on the grounds of "mere incompetence"-as implemented through agency principles ${ }^{137}$-created

131 See text following note 117 supra.

132 The state made no showing that Tompsett knew of his rights or was experienced in criminal procedure. Instead, the court relied on the accused's failure to prove he was ignorant of legal procedure. $146 \mathrm{~F} .2 \mathrm{~d}$ at 98.

133 E.g., Kinney v. United States, 177 F.2d 895 (10th Cir. 1949), cert. denied, 339 U.S. 922 (1950); Jones v. Pescor, 169 F.2d 853 (8th Cir. 1948); Tompsett v. Ohio, 146 F.2d 95 (6th Cir. 1944), cert. denied, 324 U.S. 869 (1945). See also note 229 infra and accompanying text.

134 Furthermore, to conpel the accused to carry the burden of these presumptions would hardly correct the deprivation of constitutional rights which occurred at the trial level where the prosecution had the burden of proving guilt. United States v. Lavelle, 306 F.2d 216, 219 (2d Cir. 1962).

135 People v. Kirchner, 233 Cal. App. 2d 83, 87, 43 Cal. Rptr. 218, 221 (1965).

136 Id. at 83, 43 Cal. Rptr. at 222.

137 See cases cited at note 116 supra. 
an almost insurmountable barrier for the defendant. Allegations of ineffective representation were met by mechanical recitations of agency ${ }^{l a w^{138}}$ as justification for the courts' strict position on incompetence. Thus it became nearly impossible for the convicted defendant to free himself from the bimding effect of his counsel's incompetent waiver. ${ }^{130}$

However, three general exceptions to that basic approach have gained more widespread acceptance in the past decade. The majority of courts maintain that the defendant is entitled to a new trial when the defense presented was so lacking that the trial became a farce. A small minority espouse the second view that there has been sufficient mcompetence to merit a new trial only when the state has participated in or known about counsel's incompetent acts. The third and most recent approach is to evaluate the defense actually presented in light of those that might have been offered.

\section{The Trial as a Farce}

While courts will still refuse to appraise the ability of defense counsel, ${ }^{140}$ they will usually uphold defendant's contentions when it appears that his representation was so lacking in diligence or competence that it reduced the trial to a "farce or sham."141 Such a proceeding is not accorded finality, usually on the basis that the accused has never actually received a "trial" and that he has been denied the protections of the sixth amendment. ${ }^{142}$ Of necessity, however, a standard which must evaluate the effectiveness of factors so different as trial preparation ${ }^{143}$ and tactical judgment ${ }^{144}$ must be flexible; ${ }^{145}$ and it seems that the only way

138 E.g., O'Malley v. United States, 285 F.2d 733 (6th Cir. 1961); United States ex rel. Darcy v. Handy, 203 F.2d 407 (3d Cir.), cert. denied, 346 U.S. 865 (1953); Tompsett v. Ohio, 146 F.2d 95 (6th Cir. 1944), cert. denied, 324 U.S. 869 (1945).

130 Perbaps the most extreme example of this predicament is in Archer v. Clark, 202 Ga. 229, 42 S.E.2d 924 (1947). The trial court accepted a plea of guilty, entered by defendant's attorney, despite several attempted objections by the accused. The appellate court upheld the plea, stating that the legislature had given the attorney the power to speak for his client in open court. Any allegation of ineffective representation was completely overlooked in light of the agency approach. Accord, Adams v. United States, 222 F.2d 45 (D.C. Cir. 1955).

140 E.g., Kennedy v. United States, 259 F.2d 883, 886 (5th Cir. 1958), cert. denied, 359 U.S. 994 (1959); Mitclell v. United States, 259 F.2d 787 (D.C. Cir.), cert. denied, 358 U.S. 850 (1958).

141 E.g., Umited States v. Pisciotta, 199 F.2d 603, 607 (2d Cir. 1952); Jones v. Huff, 152 F.2d 14, 15 (D.C. Cir. 1945); Alraham v. State, 223 Ind. 179, 91 N.E.2d 358 (1950). 142 See, e.g., Mitchell v. United States, 259 F.2d 787, 793 (D.C. Cir.), cert. denied, 358 U.S. 850 (1958).

143 See cases cited at note 105 supra.

144 E.g., O'Malley v. United States, 285 F.2d 733 (6th Cir. 1961).

145 See People v. Kirkrand, 14 DI. 2d 86, 91-92, 150 N.E.2d 788, 790, cert. denied, 358 U.S. 888 (1958). 
the courts have attacked the problem of definition is in negative terms: A trial is not a farce merely because the defense selected was unsuccessful ${ }^{146}$ or because the attorney made a mistake of judgment. ${ }^{147}$

The flexibility which the concept must necessarily retain as to its affirmative connotations, however, has often resulted in more of a barrier to the defendant than a protection. The vast majority of courts which have recognized the standard of "farce or sham" have applied it in such a vague manner that the defendant has had to satisfy an almost impossible burden of proof. ${ }^{148}$ Since the reviewing court itself interprets both the standard and the evidence, subjective notions of guilt or innocence will invariably arise as factors in the weighing process of the court's decision. ${ }^{148}$ Perhaps the admission of these factors is the goal of such flexibility; but if so, then the review procedure is as much a review of the outcome of the trial as it is of the trial's procedural and representational fairness.

Furthermore, most courts which give lip service to agency principles in the area of the attorney-client relationship also recognize the abovementioned exception for the trial which turns out to be a mockery of justice. ${ }^{150}$ Although none has directly explained why this degree of incompetence is not also imputed to the defendant, the decisions seem to rationalize the necessary inconsistency by holding that once the defect has gone so far, "it becomes the duty of the court or the prosecution to observe it and to correct it."151 Thus it appears that the pendulum of the agency rationale has swung, by invocation of the fourteenth amendment, toward the responsibility of the state to protect the sixth amendment right to effective assistance of counsel. ${ }^{152}$ In practice, however, this notion of judicial protection of defendant's rights has been greatly narrowed by some courts.

${ }^{146}$ Mitchell v. United States, 259 F.2d 787, 793 (D.C. Cir.), cert. denied, 358 U.S. 850 (1958).

147 Rivera v. United States, 318 F.2d 606, 608 (9th Cir. 1963); Moore v. United States, 220 F.2d 198, 199 (D.C. Cir. 1955).

148 See, e.g., Mitchell v. United States, 259 F.2d 787, 793 (D.C. Cir.), cert. denied, 358 U.S. 850 (1958); Adams v. United States, 222 F.2d 45 (D.C. Cir. 1955); United States v. Cariola, 211 F. Supp. 423 (D.N.J. 1962), aff'd, 323 F.2d 180 (3d Cir. 1963); Eendrickson v. Overlade, 131 F. Supp. 561 (D.C. Ind. 1955); Farley v. Skeen, 107 F. Supp. 881 (N.D. W. Va. 1952); In re Croft, 145 Cal. App. 2d 155, 302 P.2d 61 (1956); Jones v. Balkcon, 210 Ga. 262, 79 S.E.2d 1 (1953), cert. denied, 347 U.S. 956 (1954).

${ }^{149}$ See, e.g., Miller v. Budspeth, 164 Kan. 688, 706, 192 P.2d 147, 161 (1948).

150 E.g., Rivera v. United States, 318 F.2d 606, 608 (9th Cir. 1963); United States v. Cariola, 211 F. Supp. 423 (D.N.J. 1962), af'd, 323 F.2d 180 (3d Cir. 1963).

161 Diggs v. Welch, 148 F.2d 667, 670 (D.C. Cir.), cert. denied, 325 U.S. 889 (1945); accord, Dayton v. United States, 319 F.2d 742 (D.C. Cir.), cert. denied, 375 U.S. 947 (1963); United States ex rel. Darcy v. Eandy, 203 F.2d 407 (3d Cir.), cert. denied, 346 U.S. 865 (1953); People v. Shields, 232 Cal. App. 2d 716, 43 Cal. Rptr. 188 (1965).

102 Gideon v. Wainwright, 372 U.S. 335 (1963). 


\section{Requirement of State Action}

While the majority of courts may look to the fairness of the accused's trial and defense ${ }^{153}$-but still limit this inquiry to the extreme trial which turns out to be a farce ${ }^{154}$ - a minority have adopted a different approach which greatly limits the avenues of review for a defendant who alleges incompetent assistance of counsel. Since the due process clause of the fourteenth amendment has been applied as a restriction only upon state action, ${ }^{155}$ some state involvement is necessary for its invocation; therefore, to permit a finding of mcompetence, this minority requires that the trial court must be aware of the incompetent acts. Hence, when defendant's allegations relate to acts of incompetence outside the knowledge of the court, these courts cite the state action requirement in holding that review cannot be had on the basis of due process, since the state played no part in the alleged wrong done to the accused. ${ }^{156}$ For example, the court in United States ex rel. Wilkins v. Banmiller ${ }^{157}$ held that the due process clause was not available to the relator because the alleged act of incompetence consisted of a private communication between attorney and client. ${ }^{158}$ Since the trial court had no way to discover and correct such a "private" act of incompetence, it liad no duty to protect the relator. ${ }^{159}$

The Banmiller limitation is justifiable in that the fourteenth amendment has traditionally been limited to instances of state action. However, in applying it to the defense counsel's incompetent waivers, two difficulties are evident. First, a wholly illogical distinction-from the point of view of correcting unfairness to the defendant-is made between the effects of incompetent acts made in front of the court and those performed outside its knowledge; yet the effects of either act can be equally disastrous to defendant's rights. ${ }^{160}$ The Banmiller court recog-

\footnotetext{
153 E.g., Brubaker v. Dickson, 310 F.2d 30 (9th Cir. 1962), cert, denied, 372 U.S. 978 (1963).

154 See cases cited at note 141 supra.

155 Civil Rights Cases, 109 U.S. 3 (1883); United States ex rel. Wilkins v. Banmiller, 205 F. Supp. 123, (E.D. Pa. 1962), aff'd, 325 F.2d 514 (3d Cir. 1963), cert. denied, 379 U.S. 847 (1964).

156 E.g., Application of Hodge, 262 F.2d 778, 780-81 (9th Cir. 1958); United States ex rel. Wilkins v. Banmiller, supra note 155 ; People v. Tomaselli, 7 N.Y.2d 350, 197 N.Y.S.2d 697, 165 N.E.2d 551 (1960).

157205 F. Supp. 123 (E.D. Pa. 1962), aff'd, 325 F.2d 514 (3d Cir. 1963), cert. denied, 379 U.S. 847 (1964).

158 The attorney urged his client to plead guilty while allegedly misrepresenting certain essential facts. $I d$. at 127 .

159 Id. at 127-28.

160 The court in Holland v. Boles, 225 F. Supp. 863 (N.D. W. Va. 1963) stated: "The effect upon the accused is the same whether or not the court knew Holland was improperly represented. He has not been accorded the effective representation by counsel to which he is
} 
nized the inconsistency inherent in its reasoning: "Relator's trial may not have been a completely 'fair' one in the conceptualistic sense. However, intervention by this court requires that the denial of relator's riglits be the doing of the state." 1161 The mere nonparticipation by the state in the alleged incompetence in no way indicates a fair trial; yet this is the criterion on which the state court duty concept is based. Furthermore, the required state action is no longer difficult to find. The state prosecutes the trial, presides over the proceedings through the court system, and sometimes provides the defendant with assistance of counsel. Since Gideon v. Wainweright ${ }^{162}$ imposed the sixth amendment on the states through the fourteenth, the state action is even more evident through the recognition of the states' affirmative duty to provide a fair trial and to assure the defendant the effective assistance of counsel. ${ }^{163}$

\section{3. "Choice of Alternatives"}

These two bases of inquiry-the determination either that the trial had been a farce or that there had been some state action in the alleged incompetent acts-have not provided definite standards by which to evaluate the effectiveness of the representation. They are inherently flexible because the trial of a criminal action involves too many variables to lend itself to a neat description of what constitutes "effective assistance," and the resulting discretion of the court is often desirable. Furthermore, these standards, involving the presumption that the attorney acted competently, ${ }^{164}$ are justifiable because compliance with state procedure is encouraged and deliberate error deterred. The resulting burden of proof prevents reversal when the alleged error involves only one of the innumerable nonprejudicial errors that are possible.

However, it does seem that a more objective standard has been offered to recognize an unacceptable degree of incompetence:

constitutionally entitled under the decision of the Supreme Court in Gideon v. Wainwright ...." Id. at 866; accord, People v. Karlin, 231 Cal. App. 2d 227, 41 Cal. Rptr. 786 (1961).

161205 F. Supp. at 128.

162372 U.S. 335 (1963).

163 Cf. Powell v. Alabama, 287 U.S. 45,61 (1932).

164 See, e.g., Beckett v. Hudspeth, 131 F.2d 195 (10th Cir. 1942); People v. Harrison, 46 Cal. App. 2d 779, 117 P.2d 19 (1941). The relationship between the presumption of competent counsel and the presumption against a knowing and intelligent waiver should be noted. Compare Beckett v. Hudspeth, supra, with Johnson v. Zerbst, 304 U.S. 458 (1938). The presence of competent counsel can be presumed, because the defendant is still protected by the presumption that he or his counsel did not effectively waive a fundamental federal right. 304 U.S. at 464 . The effect of this relationship is to bind defendant presumptively to the nonfundamental waivers of his incompetent counsel but to afford him redress when an essential element of his federally guaranted rights has been abandoned. 
Facts are alleged from which it would appear that these potential defenses would have suggested themselves to a reasonably diligent trial counsel. The defense actually tendered was so insubstantial in relation to those not offered as to cast doubt upon the hypothesis that trial counsel made a deliberate informed choice. ${ }^{105}$

This "choice of alternatives" test encourages compliance with state procedure while assuring the petitioner or appellant of at least two safeguards. First, the reviewing court will not use some mechanical formula - such as agency or state participation-to reject his allegations without consideration of the merits. Second, the essence of the fifth and sixth amendments, the riglit to a fair trial, will be preserved by viewing the defense as a whole, rather than by analyzing the prejudicial effects of eacl particular action; and if the entire defense actually advanced was such an unreasonable alternative, compared to those available, then a court could find that defendant lad been denied the effective assistance of counsel. ${ }^{106}$ In this way, the standard retains its flexibility, trial decisions cannot normally be the basis for a reversal, and the specific allegations of the petitioner or appellant are viewed in the context of the entire trial.

While it is true that the standard applied by the court in Brubaker v. Dickson ${ }^{167}$ would subject some decisions of counsel to a degree of court evaluation, this would seem to be the proper role of the reviewing court when considering allegations of incompetence. Althougli most courts profess to decline to review such decisions, ${ }^{108}$ it seems that these declara-

105 Brubaker v. Dickson, 310 F.2d 30, 38 (9th Cir. 1962), cert. denied, 372 U.S. 978 (1963) ; accord, People v. Ibarra, 60 Cal. 2d 460, 386 P.2d 487, 34 Cal. Rptr. 863 (1963). This standard was impliedly rejected in OMalley v. United States, 285 F.2d 733 (6th Cir. 1961), wben the court stated, "The fact that a different or better result may have been obtained if a different decision had been made, does not mean that defendant has not had the effective assistance of counsel." Id. at 734. The O'Malley approach is, at present, the position taken by the majority of courts. On the other hand, a recent decision supported the Brubaker standard by bolding that an attorney cannot waive even the right to object to illegally obtained evidence when such a waiver would prejudice his chent's best avenue of defense. State v. Mendes, 210 A.2d 50, 55 (R.I. 1965). Cf. Brookhart v. Janis, 86 Sup. Ct. 1245 (1966).

166 An example of the apphication of this standard could be Wilson v. Gray, 345 F.2d 282 (9th Cir.), cert. denied, 382 U.S. 919 (1965), reversing 230 F. Supp. 860 (N.D. Cal. 1964). It seemed there that the preliminary transcript was so unfavorable to the defendant that the choice to hear the matter on the basis of that transcript was so unlikely to produce acquittal, in view of the other alternatives of defense, that counsel's choice was not a reasonable one. The district court called the defense a "slow plea of guilty." $230 \mathrm{~F}$. Supp. at 862 .

167310 F.2d 30 (9th Cir. 1962), cert. denied, 372 U.S. 978 (1963).

168 E.g., Rhay v. Browder, 342 F.2d 345 (9th Cir. 1965); United States ex rel. Reld v. Richmond, 295 F.2d 83 (2d Cir.), cert. denied, 368 U.S. 948 (1961); Kennedy v. United States, 259 F.2d 883 (5th Cir. 1958), cert. denied, 359 U.S. 994 (1959); Mitchell v. United States, 259 F.2d 787 (D.C. Cir.), cert. denied, 358 U.S. 850 (1958). 
tions are mere fictions; for the only process by which a court could ever determine whether ineffective assistance of counsel had rendered the trial a farce would be to evaluate the attorney's performance in relation to the accused's sixth amendment guarantee.

\section{Differences between Retained and Appointed Counsel}

An increasingly important problem in the area of the relationship between incompetent counsel and defendant is the distinction between a court-appointed attorney and one retained privately by the accused. Several courts have specifically mentioned a consequential difference between the two, ${ }^{169}$ while numerous others liave implied that one exists. ${ }^{170}$ The distinction may be valid for two reasons. Retained counsel may be given orders and instructions, whereas the indigent is forced to accept his attorney's decision or to proceed by himself, since the court will not normally appoint new defense counsel. ${ }^{171}$ Thus, if the retamed attorney acts contrary to the wishes of his client, new representation may be secured. On the other hand, the indigent accused must accept the counsel appointed by the court; he is not entitled to an attorney of his own choosing; he cannot require that attorney to carry out his instructions; and, in the absence of substantial justification, he cannot require the court to appoint another counsel. ${ }^{172}$

A second, but related area in which the difference between appointed and retained counsel may have some practical effect is in the apphication of the fourteenth amendment to the duty of state court protection. It is certainly easier to make an argument for actual state involvement $\mathrm{m}$ the alleged incompetent act when the attorney is court-appointed than it is where the counsel is privately retained. With a court-appointed lawyer, the court may have a greater affirmative duty of protection than it would in cases of retained counsel..$^{173}$

These distinctions, however, are valid only to a point. Rarely does the difference in freedom of choice have a practical effect on the outcome of the trial, since the parties are usually able to agree on some course of

169 E.g., Hendrickson v. Overlade, 131 F. Supp. 561 (N.D. Ind. 1955); People v. Kirchner, 233 Cal. App. 2d 83, 43 Cal. Rptr. 218 (1965); State v. Williams, 14 Del. 508, 18 Atl. 949 (1890).

170 E.g., Popeko v. United States, 294 F.2d 168 (5th Cir. 1961), cert. denied, 374 U.S. 835 (1963); Lotz v. Sacks, 292 F.2d 657 (6th Cir. 1961); Mitchell v. United States, 259 F.2d 787 (D.C. Cir), cert. denied, 358 U.S. 850 (1958); Tompsett v. Ohio, 146 F.2d 95 (6th Cir. 1944), cert. denied, 324 U.S. 869 (1945); People v. Martinez, 88 Cal. App. 2d 767, 199 P.2d 375 (1948), cert. denied, 337 U.S. 909 (1949).

171 People v. Shields, 232 Cal. App. 2d 716, 43 Cal. Rptr. 188 (1965).

172 Id. at 722, 43 Cal. Rptr. at 193.

173 See People v. Kirchner, 233 Cal. App. 2d 83, 89, 43 Cal. Rptr. 218, 223 (1965); State v. Williams, 14 Del. 508, 526-27, 18 Atl. 949, 951 (1890). 
action which is mutually satisfactory. If not, the defendant can often prevail upon the court to let him testify, for example, contrary to the wishes of his appointed counsel. ${ }^{174}$ Instead, it seems that the distinction is most often made as merely a rationalization to hold defendant to the acts of his retained counsel through the principles of agency. Courts have rarely used the distinction to hold a court-appointed defender to a greater degree of scrutiny; ${ }^{176}$ rather, it is more often used to emphasize the applicability of the agency doctrme in the case of retained counsel. ${ }^{178}$

Thus, there is reason to question the validity of the distinction in light of the real bases on which it is founded. First, it often seems to be merely a vehicle for the doctrine of agency, rather than an independently justifiable concept. Furthermore, where the distinction is given any practical effect in an effort to help the indigent defendant, ${ }^{177}$ it penalizes the accused who is able to afford counsel of his own choosing. The latter is held to a stricter standard, in that the court often automatically refuses to review the acts of retained counsel solely because "the choice of counsel was defendant's." ${ }^{\prime 178}$ The absurdity of reviewing an allegation of imcompetence on the basis of the petitioner's financial status seems obvious: The proceeding is designed to evaluate the fairness of the actual representation afforded defendant, without regard to the way in which counsel was chosen. ${ }^{179}$ Finally, the distinction is even more fictitious in its assumption that defendant, when hiring an attorney, is able to judge the latter's coinpetence. Barring similar previous experience, the accused has no direct way of knowing counsel's ability for preparation, diligence, and trial competence.

These rationalizations and inconsistencies lead to the conclusion that the distinction between retained and appointed counsel has no inherently justifiable basis. The actions of an attorney, no matter how selected, must be examined in light of the trial as a whole and a determination made

174 See People v. Blye, 233 Cal. App. 2d 143, 149, 43 Cal. Rptr. 231, 235 (1965).

176 E.g., People v. Kirkrand, 14 III. 2d 86, 91-92, 150 N.E.2d 788, 790, cert. denied, 358 U.S. 888 (1958). But see People v. Kirchner, 233 Cal. App. 2d 83, 89, 43 Cal. Rptr. 218, 223 (1965); People v. Morris, 3 III. 2d 437, 121 N.E.2d 810 (1954). The district court in Wilson v. Gray, 230 F. Supp. 860 (N.D. Cal. 1964), rev'd, 345 F.2d 282 (9th Cir.), cert. denied, 382 U.S. 919 (1965), implied a distinction based on the fact that the public defender in question had to help several lindred defendants a year. Id. at 866 .

178 E.g., Mitchell v. United States, 259 F.2d 787 (D.C. Cir.), cert. denied, 358 U.S. 850 (1958); Tompsett v. Ohio, 146 F.2d 95 (6th Cir. 1944), cert. denied, 324 U.S. 869 (1945); People v. Gilbert, 25 Cal. 2d 422, 154 P.2d 657 (1944).

177 E.g., People v. Kirchner, 233 Cal. App. 2d 83, 43 Cal. Rptr. 218 (1965); People v. Morris, 3 IIl. 2d 437, 121 N.E.2d 810 (1954).

178 People v. Martinez, 88 Cal. App. 2d 767, 772, 199 P.2d 375, 378 (1948), cert. denied, 337 U.S. 909 (1949).

179 People v. Fryson, 36 Misc. 2d 73, 75-6, 232 N.Y.S.2d 224, 228 (Sup. Ct. 1962); accord, Holland v. Boles, 225 F. Supp. 863, 865-66 (N.D. W. Va. 1963). 
whether that representation was so inadequate as to deprive the accused of his right to a fair trial and to effective assistance of counsel. ${ }^{180}$ If that assistance was absent, the manner of selection would seem to be of no consequence.

\section{III}

\section{PRESENCE OF EXCEPTIONAL CIRCUMSTANCES}

There are several other factors which courts consider in binding the defendant to a waiver of his federal rights. The most common approach is to assume that the waiver is binding, absent "exceptional circumstances." ${ }^{181}$ Thus, trial decisions, reasonably made by competent counsel, cannot normally be attacked. ${ }^{182}$ Any less stringent rule would make the trial a farce, in that it would greatly destroy the utility of a defense attorney and would enable defendant to attack collaterally the decision of a trial court any time his counsel made a liarmless error. Therefore, accused persons are not guaranteed a flawless defense; ${ }^{183}$ and many courts adopt a presumption in favor of regularity, ${ }^{184}$ which will stand unless the defendant can show that the waiver was made under circumstances that deprived him of an effective choice. ${ }^{185}$ The presently accepted doctrime and its relation to the Fay test is perhaps stated most succinctly in Henry:

Although trial strategy adopted by counsel without prior consultation with an accused will not, where the circumstances are exceptional, preclude the accused from asserting constitutional claims, ... we think that the deliberate bypassing by counsel of the conteinporaneousobjection rule as a part of trial strategy would lave that effect in this case. ${ }^{188}$

While the exact nature of these "exceptional circumstances" is by no means clear, there have been some significant examples of the use of this

180 Brubaker v. Dickson, 310 F.2d 30 (9th Cir. 1962), cert. denied, 372 U.S. 978 (1963); Abraham v. State, 228 Ind. 179, 91 N.E.2d 358 (1950).

181 E.g., Henry v. Mississippi, 379 U.S. 443, 452 (1965); Brown v. Allen, 344 U.S. 443, 503 (1953) (opinion of Frankfurter, J.). Compare the Ianguage used in Fay v. Noia, 372 U.S. 391,438 (1963).

182 E.g., Rhay v. Browder, 342 F.2d 345 (9th Cir. 1965); United States ex rel. Reid v. Richmond, 295 F.2d 83 (2d Cir.), cert. denied, 368 U.S. 948 (1961); Kennedy v. United States, 259 F.2d 883 (5th Cir. 1958), cert. denied, 359 U.S. 994 (1959); Mitchell v. United States, 259 F.2d 787 (D.C. Cir.), cert. denied, 358 U.S. 850 (1958); People v. Campbell, 233 Cal. App. 2d 38, 43 Cal. Rptr. 237 (1965); People v. Mitchell, 411 IIl. 407, 104 N.E.2d 285, cert. denied, 343 U.S. 969 (1952).

183 See note 103 supra and accompanying text.

184 See, e.g., Beckett v. Hudspeth, 131 F.2d 195, 197 (10th Cir. 1942); People v. Harrison, 46 Cal. App. 2d 779, 783, 117 P.2d 19, 22 (1941).

185 E.g., Fay v. Noia, 372 U.S. 391, 440 (1963); Whitus v. Balkcom, 333 F.2d 496, 509 (5th Cir.), cert. denied, 379 U.S. 931 (1964).

186379 U.S. at 451-52. (Emphasis added.) 
doctrine to disregard what would otherwise have been an effective waiver of constitutional rights. For example, in Whitus v. Balkcom ${ }^{187}$ a Negro defendant and his counsel were faced with the choice of accepting either an all-white jury or a community atmosphere of hostility produced by an attack on such a jury. ${ }^{188}$ The court found that the defendant could not be held to a waiver made under such conditions, even though deliberate: "The petitioners and their attorneys had no desire to give up their right to be tried by a jury chosen without regard to the race of the jurors. It was not in their interest to do so-except as a choice of evils."180

Fay v. Noia, ${ }^{100}$ involved a similar choice of evils. Even though defendant had intentionally chosen not to appeal, the Court held that this was not a binding waiver because it was forced upon him by having to make the "grisly choice"191 between accepting a conviction obtained with the use of an admittedly coerced confession or else appealing that conviction with the acute possibility that retrial ${ }^{192}$ would bring a death sentence instead of life imprisonment. ${ }^{193}$ The Court seemed to base its decision on two grounds but failed to make an effective distinction between them. After formulating the dehiberate bypass standard, the majority held that Noia's failure to appeal was not a deliberate circumvention of state procedure, even though it was intentional, because of the exceptional circumstances which had forced him to make the "grisly choice." The defendant, therefore, had not effected a dehiberate bypass, according to federal standards ${ }^{104}$ and was not precluded from a hearing on the merits of his federal claim. On the other hand, the decision also held that habeas courts had the power to overlook the state procedural default. ${ }^{105}$ The Court stated that even though Noia had actually waived access to the appellate process, a federal habeas court could refuse "to concede jurisdictional significance to the abortive state court proceeding"100 and thereby render the prior waiver ineffective in relation to the habeas hearing. ${ }^{107}$ The first approach denies the existence of a waiver, whereas

187333 F.2d 496 (5th Cir.), cert. denied, 379 U.S. 931 (1964).

188 Id. at 499 .

189 Id. at $498-99$.

190372 U.S. 391 (1963).

191 Id. at 440 .

192 The retrial rule was held constitutional in Stroud v. United States, 251 U.S. 15 (1919). But see Green v. United States, 355 U.S. 184 (1957); People v. Fenderson, 60 Cal. 2d 482, 497, 386 P.2d 677, 686, 35 Cal. Rptr. 77, 86 (1963).

193 This was especially likely because the sentencing judge had nade certain harsh remarks to the defendant. 372 U.S. at 397.

194 Id. at 439 .

105 Id. at 422,426 .

190 Id. at 426.

107 In vitiating what would otherwise be an effective waiver, exceptional circunustances such as these are normally considered by a federal court pursuant to its discretionary power 
the latter rationale is based on the habeas courts' discretionary power to overlook what otherwise would have been an effective waiver. ${ }^{198}$

While a court can often strain to find such exceptional circumstances when it wishes to reverse a conviction, the doctrine more frequently has been turned against the defendant by affirmance of the conviction due to the absence of such factors. ${ }^{199}$ "A federal court may not grant a writ of habeas corpus to a state prisoner, save in exceptional circumstances, unless the prisoner has availed himself of one of the corrective processes available in the courts of the state." ${ }^{200}$ In these cases the defendant is normally forced to bear the burden of demonstrating such circumstances in order to win a hearing on the merits. ${ }^{201}$ In United States ex rel. Kozicky v. $F a y,{ }^{202}$ for instance, the alleged failure of counsel to file an appeal because of his client's indigence did not vitiate defendant's waiver, since the state had provided remedial procedures. Therefore, argument on the claim of a coerced confession was never heard because defendant failed to demonstrate that the waiver had been attended by exceptional circumstances. $^{203}$

The difficulty with this approach is that several courts have applied it so that the defendant is forced to assume the burden of proof that his waiver was made under exceptional circumstances. ${ }^{204}$ This application,

"to hold an evidentiary hearing and determine the facts." Id. at 422; accord, Townsend v. Sain, 372 U.S. 293, 312-13 (1963); Brown v. Allen, 344 U.S. 443, 463 (1953). Federal courts may also disregard the defendant's failure to exhaust state remedies under 28 United States Code, section 2254, since "discretion was the flexible concept employed by the federal courts in developing the exhaustion rule." Fay v. Noia, supra, at 438.

198 While both these approaches are sanctioned by the Fay Court, that which says, in effect, there never was a forfeiture seems to be less consistent with the entire rationale adopted by the Court in waiver situations. Noia's bypass was understanding and knowingthus fitting the Johnson definition of waiver-and was also intentional-coming within Fay's dehberate bypass standard. The better doctrinal approach-also adopted in Faywas to recognize the effective waiver while at the same time recognizing the habeas courts' discretionary power to overlook it when defendant is forced to make a choice of evils.

189 See, e.g., Mitchell v. United States, 259 F.2d 787 (D.C. Cir.), cert. denied, 358 U.S. 850 (1958); United States ex rel. Kozicky v. Fay, 248 F.2d 520 (2d Cir. 1957), cert. denied, 356 U.S. 960 (1958).

200 United States ex rel. Kozicky v. Fay, supra note 199, at 521.

201 Wilson v. Gray, 345 F.2d 282, 289 (9th Cir.), cert. denied, 382 U.S. 919 (1965): "Clearly, the instant case is not one 'where the circumstances are exceptional' so as to preclude the finding of an effective waiver of the right in question of the accused by his counsel."

202248 F.2d 520 (2d Cir. 1957), cert. denied, 356 U.S. 960 (1958).

203 Id. at 522 .

204 See cases cited note 199 supra. This would create the following anomaly: Whitus' conviction was set aside because his attorney failed to object under exceptional circumstances. Whitus v. Balkcom, 333 F.2d 496 (5th Cir.), cert. denied, 379 U.S. 931 (1964). But a defendant whose attorney failed to make the same objection under "normal" trial conditions would be equally prejudiced by such failure but unable to vitiate it because his trial had progressed too normally. 
when not used in conjunction with the deliberate bypass standard, would seem to be contrary to the principle that courts "do not presume acquiescence in the loss of fundamental rights. ${ }^{205}$ Moreover, the concept fails to provide adequate standards for the guidance of federal habeas courts. ${ }^{208}$

Its use is justifiable, however, in that it furnishes the courts with desirable flexibility and encourages compliance with state procedure, since the defendant knows that a federal court will not exercise its discretion to overlook noncompliance with the state's rules unless exceptional circumstances can be proved. The concept is also an essential. palliative to the deliberate bypass standard for the defendant who is forced to make a deliberate choice of evils: His waiver may satisfy the knowing, intelligent, and deliberate bypass standards of Fay and Johnson; ${ }^{207}$ but the position of having to make such a clioice constitutes sufficiently exceptional circumstances to vitiate the waiver. Thus, the doctrine of exceptional circumstances and the deliberate bypass approach complement each other by encouraging compliance with state procedure while protecting the accused from unintentional or involuntary waivers.

\section{IV}

\section{RECORDATION OF WATVERS}

While the Constitution demands that every criminal defendant receive a fair trial, it leaves to the states the procedural details for ensuring that fairness. ${ }^{208}$ To date, the states have been extremely reluctant to impose on their court systems the duty of recording defendant's waivers, and the Umited States Supreme Court has not held recordation to be a constitutional requirement. ${ }^{209}$ Thus, a contention of non-recordation, by itself,

205 Johnson v. Zerbst, 304 U.S. 458, 464 (1938), quoting from Ohio Bell Tel. Co. v. Public Util. Comm'n, 301 U.S. 292, 309 (1937) ; accord, Carnley v. Cochran, 369 U.S. 506, 516 (1962). But see Moore v. Michigan, 355 U.S. 155, 161-62 (1957); see also note 134 supra and accompanying text. There are some recognized exceptions, lowever, to the Johnson holding. For instance, the privilege against self-incrimination is deemed waived unless invoked. Rogers v. United States, 340 U.S. 367, 370 (1951).

206 Townsend v. Sain, 372 U.S. 293, 313 (1963).

207 The Fay Court implied, however, that wben the defendant was put to such choice, his waiver is not really "deliberate." 372 U.S. at 440 . This seems to strain the Court's own definition of the standard, since Noia's choice was both conscious and understanding. See note 198 supra.

208 See, e.g., Carter v. Mlinois, 329 U.S. 173, 175 (1946); McKane v. Durston, 153 U.S. 684 (1894). It can be argued, however, that state determination of procedural matters has actually been eroded sub silentio by Pointer v. Texas, 380 U.S. 400 (1965), and Henry v. Mississippi, 379 U.S. 443, 446-48 (1965).

209 See Gray v. Wilson, 230 F. Supp. 860,867 (N.D. Cal. 1964), rev'd on other grounds, 345 F.2d 282 (9th Cir.), cert. denied, 382 U.S. 919 (1965). 
would be insufficient grounds to vitiate an alleged waiver. However, several courts, when faced with the problem of determining whether there was an effective waiver, have been influenced by the presence or absence of information in the record; and since a waiver cannot be presumed, ${ }^{210}$ they have been able to take the position that there can be no waiver "when the record is silent or inconclusive concerning knowledge."211 On the other hand, some courts have been prone to rely on the fact that there is no indication in the record that defendant disagreed with his attorney's actions; and they therefore consider that the client has made some sort of ratification of the waiver. ${ }^{212}$ The fallacy inherent in this approach is the highly unlikely presumption that defendant was aware of his rights, especially those of a procedural nature. ${ }^{213}$

It would be an impossible burden on court administration to require that every waiver be recorded. Indeed, most trial waivers cannot be registered because they do not consist of affirmative acts. ${ }^{214}$ Yet adherence to the policies of personal waiver in Fay and of nonpresumption in Johnson v. Zerbst may require some recordation of certain relinquishments if the state is to protect itself from later collateral attack. ${ }^{215}$ The

210 E.g., Carnley v. Cochran, 369 U.S. 506, 516 (1962); Johnson v. Zerbst, 304 U.S. 458, 464 (1938). But see Moore v. Michigan, 355 U.S. 155, 161-62 (1957).

211 Wood v. United States, 128 F.2d 265, 277 (D.C. Cir. 1942). The Supreme Court in Camley v. Cochran, supra note 210, gave support to this position by stating, "Presuming waiver from a silent record is impermissible. The record must show, or there must be an allegation and evidence which show, that an accused was offered counsel but intelligently and understandingly rejected the offer. Anything less is not waiver." Id. at 516 ; accord, Whitus v. Balkcom, 333 F.2d 496, 502 (5th Cir.), cert. denied, 379 U.S. 931 (1964); United States ex rel. Goldsby v. Harpole, 263 F.2d 71 (5th Cir.), cert. denied, 361 U.S. 838, 850 (1959); State v. Mendes, 210 A.2d 50 (R.I. 1965); People v. Stewart, 62 Cal. 2d 571, 581, 400 P.2d 97, 103, 43 Cal. Rptr. 201, 207 (1965).

212 E.g., Tompsett v. Ohio, 146 F.2d 95, 98 (6th Cir. 1944), cert. denied, 324 U.S. 869 (1945).

213 People v. Kirchner, 233 Cal. App. 2d 83, 87, 43 Cal. Rptr. 218, 222 (1965).

214 Intentional or unintentional waiver of the right to cross examine and make objection to the introduction of illegally obtained evidence, for example, consists merely of silence on the part of either counsel or defendant. Since the judge or prosecution will often not recognize circumstances in which defense counsel has waived his chent's rights, there is no way to ascertain whether such relinquishment was debiberate, knowing, and personal. Furthermore, even if this were possible, judicial efficiency would suffer greatly if the proceeding had to be abruptly stopped to inquire about the nature of the waiver.

${ }^{215}$ Confirmation of defendant's stipulation for a trial on the transcript of the preliminary hearing, of his waiver of the right to counsel, or even of his right to take the stand to testify would provide presumptive proof of defendant's personal participation in the waiver and would eliminate subsequent attacks on those grounds. The trial court in the Wilson case, for example, recorded the accused's response to questions regarding the waiver of his right to a jury and thereby prevented habeas consideration of that poimt, since there was recorded confirmation of an affirmative, personal waiver. The same court, however, failed to inquire into and to record the stipulation of trial on the transcript of the 
problem, then, lies in retaining court efficiency while advancing defendant's protection against inadvertent waiver of his constitutional rights.

It has been suggested that the same considerations apply to the necessity of recordation that apply to the requirement of consultation between client and attorney: When there is an opportunity to determine defendant's participation, knowledge, and understanding for the record, judicial efficiency would seem to demand that it be done. ${ }^{210}$ The Conference of State Chief Justices made such a proposal in 1953:

The convicting court should at time of arraignment, plea, and sentence in open court cause inquiry to be made of the defendant and record of his responses to be kept concerning his understanding of his rights and the voluntary character of any waiver thereof. The journal of the court should set forth the faots .... . .17 $^{217}$

This procedure would coincide with and complement the court's inquiry as to the defendant's intention and concurrence in the waiver, although it would not protect him from an unintelligent or uninformed waiver. Furthermore, since a stenographic record is usually presumed to be correct, ${ }^{218}$ such an inquiry would preclude fraudulent claims of unintentional waiver in a subsequent habeas corpus or coram nobis proceeding. This factor unay assume greater importance with the increasing insistence on procedural protections of substantive riglts. Thus, while recordation is not now constitutionally required, some type of written confirmation would seem expedient from the point of view of protecting the interests of the defendant, the court, and the prosecution.

preliminary hearing and thus gave rise to the possible grounds of reversal considered in Gray v. Wilson, 230 F. Supp. 860 (N.D. Cal. 1964), rev'd, 345 F.2d 282 (9th Cir.), cert. denied, 382 U.S. 919 (1965). To protect themselves against subsequent collateral attack, Massachusetts, West Virginia, and North Carolina now require a written waiver of the right to counsel. See Silverstein, The Continuing Impact of Gideon v. Wainwright on the States, 51 A.B.A.J. 1023 (1965).

210 "At the same time we have recognized that there are some rights of so vital a nature that the record must give assurance that the waiver was that of the defendant acting after full professional advice from his counsel with at least some understanding of the significance of the course pursued or the right foresaken." Adams v. United States, 302 F.2d 307, 314 (5th Cir. 1962) (dissenting opinion); accord, United States ex rel. Goldsby v. Harpole, 263 F.2d 71, 83 (5th Cir.), cert. denied, 361 U.S. 838, 850 (1959).

217 Report of the Special Committee on Habeas Corpus to the Conference of Chief Justices, June 1953, reprinted in Hearings on H.R. 5649 Before Subcommittee No. 3 of the House Committee on the Judiciary, 84th Cong., 1st Sess. 93 (1955). Compare the procedure used by the trial judge in Wilson in substantiating defendant's waiver of the right to trial by jury. See note 215 supra.

218 E.g., Henry v. State, 154 So. 2d 289, 293 (Miss. 1963), vacated on other grounds, 379 U.S. 443 (1965); Huffman v. Alexander, 197 Ore. 283, 317, 251 P.2d 87, 102 (1952). 


\section{DEFENDANT'S BACKGROUND}

The background and experience of the accused have been infrequent factors in the courts' determination of the effect of an abandonment of federal rights. Rarely has a waiver decision relied either wholly or essentially on questions of defendant's age, educational background, or criminal experience. ${ }^{219}$ The presence of these factors has been used more to support a conclusion based primarily on other grounds, such as a deprivation of counsel. ${ }^{220}$ Like recordation, these considerations are weighed as a part of the habeas courts' discretionary power. In considering a petition to vitiate a trial waiver, this discretion can be extended to a critical factual imquiry into the "particular facts and circumstances surrounding that case, including the background, experience, and conduct of the accused."221 On direct appeal, these factors may determine defendant's capability for effecting a knowing and intelligent waiver. ${ }^{222}$

The decision in Crooker v. California, ${ }^{223}$ for example, placed great stress upon the defendant's educational background. In denying claims that he had been prejudiced by lack of counsel, the Court referred to Crooker's legal education. The accused, the Court said, was thereby familiar with the various constitutional rights which he claimed were lost because of the denial of an attorney. ${ }^{224}$ In DeMeerleer v. Michigan, ${ }^{225}$ the Supreme Court reversed the inurder conviction of a seventeen-yearold defendant who had been "hurried through unfamiliar legal proceedings, ${ }^{, 228}$ had pleaded guilty, and had been arraigned, convicted, and sentenced in one day. The trial court had failed to provide counsel, and this denial was presumed to have prejudiced a person of defendant's youth and limited experience. ${ }^{227}$ But where an accused had been charged with

219 But see cases cited in notes 223-29 infra and discussed in accompanying text.

220 E.g., DeMeerleer v. Michigan, 329 U.S. 663 (1947).

221 Johnson v. Zerbst, 304 U.S. 458,464 (1938); accord, Brubaker v. Dickson, 310 F.2d 30, 32 (9th Cir. 1962), cert. denied, 372 U.S. 978 (1963).

222 See Crooker v. California, 357 U.S. 433 (1958); DeMeerleer v. Michigan, 329 U.S. 663 (1947).

223357 U.S. 433 (1958). The specific issue in Crooker was the failure of police to let defendant contact his attorney on request. However, this failure was alleged to have prejudiced Crooker when he later waived his right to remain silent during police interrogation. Id. at 436-37.

224 Id. at 438. Crooker was a thirty-one-year-old college graduate who had attended one year of law school. There was some evidence, however, that he was emotionally unstable.

225329 U.S. 663 (1947).

$226 I d$. at 665.

${ }^{227}$ Cf. Tompsett v. Ohio, 146 F.2d 95 (6th Cir. 1944), cert. denied, 324 U.S. 869 
similar offenses over a period of years, his attorney's unreasonable advice to plead guilty was not reviewable. ${ }^{228}$ Any alleged incompetence of the lawyer was held not to affect the defendant because of his familiarity with criminal procedure, and the latter was held to be bound by the waiver. ${ }^{229}$

Other opinions, however, have rejected the use of environmental and intellectual factors. Mr. Justice Douglas, for instance, felt the right to counsel was "too fundamental and absolute to allow courts to indulge in mice calculations as to the amount of prejudice ${ }^{230}$ a waiver may create. He would have held Crooker to a normal standard of understanding. However, the logical extension of the rationale of this position would also disregard the ignorance of the uneducated defendant who "unintelligently" consented to the waiver of an essential element of his defense.

Whether through acceptance of Justice Douglas' approach or through considerations of the practical limits of judicial inquiry, courts have largely ignored these factors. Where defendant's background or experience has been determinative, however, the accused has usually been either highly educated, unusually ignorant, or extremely familiar with the criminal procedures involved; and these considerations have been used as evidence in evaluating the understanding and intelligent nature of the waiver in question.

\section{VI}

\section{LEGITILATE STATE INTEREST}

The various factors previously examined have been cited by courts in an attempt to evaluate the circumstances under which the waiver was effected. A further consideration-to be distinguished from defendant's reasons for departing from a particular state procedural rule-is the reasonableness of the rule itself. ${ }^{231}$

While the Court has long maintained that the mere presence of a federal question does not render state procedural requirements inappli-

(1945). The court there held that it would impute the attorney's waiver to his client except in those cases in which the defendant was too ignorant of his legal rights to personally object. Id. at 98 .

228 Kinney v. United States, 177 F.2d 895 (10th Cir. 1949), cert. dentied, 337 U.S. 922 (1950); accord, Jones v. Pescor, 169 F.2d 853 (8th Cir. 1948), in which there was no prejudicial denial of counsel where defendant was himself an attorney. But see United States v. Tribote, 297 F.2d 598 (2d Cir. 1961), in which defendant's previous experience in state courts did not justify an inference that he knew his rights.

229 Kinney v. United States, supra note 228 , at 897.

230 Crooker v. California, 357 U.S. 433, 442 (1958) (Douglas, J., dissenting), quoting fronu Glasser v. United States, 315 U.S. 60, 76 (1942).

231 Compare id. at 448-49, with Henry v. Mississippi, 379 U.S. 443, 451 (1965). 
cable, ${ }^{232}$ it has also held that the preclusive effect of the procedural default is a federal question to be determined by federal courts. ${ }^{233}$ However, the Court has hesitated, in evaluating the state court findings on waiver, to make a determination of the state's motives for establishing the procedural rule waived. Instead, it has confined its inquiry to the reasonableness of the rule's application, ${ }^{234}$ to its discriminatory effect on the presentation of federal claims, ${ }^{235}$ and to the rule's support in state law. ${ }^{236}$

The Henry decision, however, seems to indicate a new willingness to look behind the façade of the state procedural ground. The opinion's rationale in this area is based on two principles: first, the recognition that the federal substantive interest predominates over the state procedural requirements; ${ }^{237}$ and second, the complementary holding that when the state ground is procedural, the presence of federal issues may vitiate the procedural imperfection. ${ }^{238}$ If $F$ ay left any doubt as to what standard would be applied by federal courts in reviewing waivers of state procedural requirements, Henry cleared the air:

A procedural default which is held to bar challenge to a conviction in state courts, even on federal constitutional grounds, prevents implementation of the federal right. Accordingly, we have consistently held that the question of when and how defaults in compliance with state procedural rules can preclude our consideration of a federal question is itself a federal question. ${ }^{239}$

The approach reveals the Court's determination to apply federal standards of waiver ${ }^{240}$ and to evaluate the particular procedural requirement, ${ }^{241}$ the considerations for which it was adopted, and the method in which it was applied.

One factor which the Court seems to regard as essential in this process

232 Herb v. Pitcairn, 324 U.S. 117 (1945); John v. Paullin, 231 U.S. 583, 585 (1913).

293 Henry v. Mississippi, 379 U.S. 443, 447 (1965); Lovell v. City of Griffin, 303 U.S. 444, 450 (1938); Carter v. Texas, 177 U.S. 442 (1900).

234 E.g., Staub v. City of Baxley, 355 U.S. 313, 320 (1958); Whitus v. Balkcom, 333 F.2d 496, 505 (5th Cir.), cert. denied, 379 U.S. 931 (1964).

235 E.g., Fay v. Noia, 372 U.S. 391, 432 (1963); Williams v. Georgia, 349 U.S. 375, 383 (1955); accord, Staub v. City of Baxley, supra note 234, at 329 (Frankfurter, J., dissenting).

236 E.g., Staub v. City of Baxley, supra note 234, at 320; Williams v. Georgia, supra note 235 , at 383 .

237379 U.S. at 446-48; accord, Fay v. Noia, 372 U.S. 391, 431 (1963).

238379 U.S. at 447.

239 Ibid.; see Dice v. Akron, C. \& Y.R.R., 342 U.S. 359 (1952).

240 For example, the deliberate bypass test and the exceptional circumstances doctrine will be used by federal courts to analyze a waiver question, no matter what guideline has been used in the state proceeding. 379 U.S. at $447-50$.

241 Id. at $448-49$. 
of evaluation is the presence of a legitimate state interest. ${ }^{242}$ The test itself is by no means a new one, ${ }^{243}$ and the Court acknowledged that Mississippi's contemporaneous objection rule served such an interest. ${ }^{244}$ The modification which the Henry case suggests, however, hes in its analysis of the satisfaction of that interest. Instead of automatically halting its imquiry when such grounds were raised and their legitimacy approved, ${ }^{245}$ the Henry Court continued its investigation by trying to determine whether the state interests which formed the basis of the contemporaneous objection rule had been satisfied in some other manner or at some other point in the trial. It was found that a motion for a directed verdict, made at the close of the state's evidence, may have served the same purposes of the procedural rule by apprising the judge of the specific objection to that evidence. ${ }^{246}$ Under these circumstances, rehance upon the contemporaneous objection rule to preclude presentation of federal claims "would be to force resort to an arid ritual of meaningless form."247 Thus, while the Court had previously refused to continue its consideration once mere noncompliance had been determined, ${ }^{248}$ it is now willing to search the record ${ }^{249}$ to find an act serving equivalent state interests. ${ }^{250}$

This difference in approach is the main indication that the Court is now willing to tolerate a lesser degree of compliance with state procedural rules in order to limit the application of the waiver doctrine when federal questions are involved. When the state determination of waiver is based on the intentional noncompliance with rules of procedure, the binding effect is beyond question, ${ }^{251}$ unless those rules or their application serve

242 Id. at 447.

243 See, e.g., Staub v. City of Baxley, 355 U.S. 313, 319 (1958).

244379 U.S. at 448.

245 See the approach used by the Court in Edelman v. California, 344 U.S. 357, 358-59 (1953).

246379 U.S. at $448-49$.

247 Staub v. City of Baxley, 355 U.S. 313,320 (1958).

248 See, e.g., Brown v. Allen, 344 U.S. 443 (1953); Edelman v. California, 344 U.S. 357 (1953).

249379 U.S. at 248-50. But see note 250 infra.

250 The approach in Staub was similar, in that the particular application of the procedural rule was deemed unreasonable. Despite the legitimacy of the rule on its face, it was leld that the failure to list the particular sections of the ordinance in question was an inadequate state ground when the entire ordinance was being challenged. 355 U.S. at 320 (1958). The Court in Henry, though, searclied much luarder to find the possible inadequacy, since it is questionable whether a notion for a directed verdict served the same interests as a timely objection to the introduction of evidence. For example, it certainly does not serve the important function of keeping tainted evidence from the jury. See Henry $v$. Mississippi, 379 U.S. 443, 462-63 (1965) (Harlan, J.9 dissenting).

251 Henry v. Mississippi, 379 U.S. 443, 451-52 (1965). The exception to this guideline is found when state substantive and procedural rules combine to force defendant to make a "grisly choice." See note 191 supra and accompanying text. 
no legitimate state interest. On the other hand, when no such intent is proved, the petitioner will be given an opportunity to show that the legitimate state interests have been served through comphance with other rules $^{252}$ and thereafter to prove that a binding waiver was not effected. If such inadequacy be established, a hearing on the merits of petitioner's federal claims will no longer be precluded. ${ }^{253}$

\section{CONCLUSION}

The dramatic expansion of federal substantive rights for those accused of crime has been complemented by an equally important pliase in the development of the procedural protection of those rights. Perhaps the overriding spirit-if not precedent-for this concurrent growth has been the implied application of the Dice v. Akron, C. \& Y.R.R. ${ }^{254}$ principles to the concepts of waiver, resulting in the recognition that the federal interest in the assurance of constitutional rights is paramount. ${ }^{265}$ This framework has enabled the courts to move from the arbitrary position of Tompsett and Daniels to the more flexible grounds of Fay, Whitus, and Henry. Thus, the requirement of either defendant's personal waiver or his counsel's intentional waiver of fundamental rights has been increasingly developed in these latter cases; and the approach that the federal courts now seem to be adopting enables them to weigh the various factors involved in an intelligent and understanding relinquishment, rather than to apply the mecliamical principles of agency law. Also, the application of the principles of personal waiver has been and can continue to be himited to those waivers that affect fundamental rights and which are made when there is an opportunity for consultation, so that judicial efficiency does not suffer while inadvertent waiver is curtailed. The effect of considering defendant's participation, counsel's incompetent waiver, the circumstances surrounding the forfeiture, and the nature of the right waived is not to increase the accused's substantive rights. Rather, the impact is felt $\mathrm{m}$ the recognition that the purpose of procedural rules is to effectuate federal substantive rights. Moreover, while these cases recognize the importance of state procedures, they no longer accord absolute finality to the failure to perfect such requirements when the procedure has become a barrier to the individual instead of a means for orderly administration of criminal justice. ${ }^{256}$

252 Id. at 448-49.

203 Id. at $452-53$.

254342 U.S. 359 (1952).

255 Fay v. Noia, 372 U.S. 391,431 (1963).

$250 I d$. at $43 \%$; Staub v. City of Baxley, 355 U.S. 313, 320 (1958); Whitus v. Balkcom, 333 F.2d 496 (5th Cir.), cert. denied, 379 U.S. 931 (1964). Professor Pollak describes the transition well: "[C]oncepts [of finality], like stare decisis, stem from the principle that 'in most matters it is more important that the applicable ... rule . . . be settled than 
However, the courts' discretion in evaluating the waiver itself and its effect on subsequent review does not mean the total deterioration of state procedural requirements that some observers would suggest. ${ }^{207}$ First, it has been made explicitly clear that the deliberate bypass of state procedure will not be tolerated, whether for strategic or other reasons, ${ }^{268}$ unless that procedure serves no legitimate state interest or is imposed in exceptional circumstances. The necessities of comity-by whicl the federal and state judicial systems recognize the interests of each other-require that the federal judge have the discretion to deny relief to any defendant who has intentionally evaded the state requirements. Furthermore, since a decision in a state court is not res judicata in respect to habeas proceedings, ${ }^{259}$ the state result could not prejudice the defendant's later petition to a federal liabeas court. Thus, a defendant who is acting intentionally and on rational principles will not clroose to bypass state procedure, unless that procedure requires him to make a Hobson's clroice of evils, in which case he will not be held to his decision. ${ }^{260}$ Finally, the flexibility of review after inadvertent waiver in no way diminishes the importance of state procedural rules. Arbitrary dismissal of an appeal or petition would serve no deterrent function since the waiver was umintentional; and any gain in judicial administration which might be induced by sucl rigidity would be nore than offset by the permanent denial of essential constitutional protections.

The challenge to the intolerable consequences of the Tompsett and Daniels approaches has been squarely faced by the Fay and Henry courts. The trend of judicial decisions in the area of procedural waiver has continued to recognize that there must be some sanctions for noncompliance with procedural requirements. The former concepts of waiver failed to develop a framework in which the concept of forfeiture could be flexibly apphed. The doctrines of personal waiver and deliberate bypass have greatly contributed to the solution of this dilemma and lave created a structure in which the accused can find an acceptable balance between constitutional protections and state procedural interests.

Kenneth A. Goldman

\footnotetext{
that it be settled right.' But where personal hiberty is involved, a democratic society employs a different arithmetic and insists that it is less important to reach an unshakable decision than to do justice." Pollak, Proposals to Curtail Federal Habeas Corpus for State Prisoners: Collateral Attack on the Great Writ, 66 Yare L.J. 50, 65 (1956). 257 E.g., Henry v. Mississippi, 379 U.S. 443, 457 (1965) (Harlan, J., dissenting); Fay v. Noia, 372 U.S. 391, 448 (1963) (Harlan, J., dissenting).

258 Henry v. Mississippi, supra note 257, at 451 ; Fay v. Noia, supra note 257 , at 438 . 259372 U.S. at 422.

280 Id. at $439-40$.
} 